\title{
The role of non-coding RNAs in the regulation of stem cells and progenitors in the normal mammary gland and in breast tumors
}

\author{
Chiara Tordonato ${ }^{1}$, Pier Paolo Di Fiore ${ }^{1,2,3}$ * and Francesco Nicassio ${ }^{4}$ * \\ ${ }^{1}$ Department of Experimental Oncology, European Institute of Oncology, Milan, Italy \\ ${ }^{2}$ Fondazione Istituto FIRC di Oncologia Molecolare, Milan, Italy \\ ${ }^{3}$ Dipartimento di Scienze della Salute, Università degli Studi di Milano, Milan, Italy \\ ${ }^{4}$ Center for Genomic Science of IIT@SEMM, Istituto Italiano di Tecnologia, Milan, Italy
}

\section{Edited by:}

Yonggang Zhou, Max Planck Institute for Heart and Lung Research,

Germany

\section{Reviewed by:}

Lucia Altucci, Seconda Università degli Studi di Napoli, Italy

Cinzia Allegrucci, University of Nottingham, UK

\section{*Correspondence:}

Francesco Nicassio, Center for Genomic Science of IIT@SEMM, Istituto Italiano di Tecnologia, C/O Campus IFOM-IEO, Via Adamello 16 20139 Milan, Italy

e-mail: francesco.nicassio@iit.it; Pier Paolo Di Fiore, Department of Experimental Oncology, European Institute of Oncology - Fondazione Istituto FIRC di Oncologia Molecolare, Via Adamello 16, 20139 Milan, Italy e-mail: pierpaolo.difiore@ieo.eu
The outlook on stem cell (SC) biology is shifting from a rigid hierarchical to a more flexible model in which the identity and the behavior of adult SCs, far from being fixed, are determined by the dynamic integration of cell autonomous and non-autonomous mechanisms. Within this framework, the recent discovery of thousands of non-coding RNAs (ncRNAs) with regulatory function is redefining the landscape of transcriptome regulation, highlighting the interplay of epigenetic, transcriptional, and post-transcriptional mechanisms in the specification of cell fate and in the regulation of developmental processes. Furthermore, the expression of ncRNAs is often tissue- or even cell typespecific, emphasizing their involvement in defining space, time and developmental stages in gene regulation. Such a role of ncRNAs has been investigated in embryonic and induced pluripotent SCs, and in numerous types of adult SCs and progenitors, including those of the breast, which will be the topic of this review. We will focus on ncRNAs with an important role in breast cancer, in particular in mammary cancer SCs and progenitors, and highlight the ncRNA-based circuitries whose subversion alters a number of the epigenetic, transcriptional, and post-transcriptional events that control "stemness" in the physiological setting.

Keywords: non-coding RNA, miRNA, IncRNA, stem cell, cancer stem cell, mammary gland, breast cancer

\section{BIOGENESIS AND FUNCTIONS OF miRNAs AND InCRNAs}

The "non-coding revolution" has completely shifted our view of gene expression programs, which have historically been based on the assumption that only protein coding genes could specify cellular functions. Recent research has highlighted the existence of numerous species of non-coding RNAs (ncRNAs) and provided compelling evidence of a significant regulatory role of these molecules, impacting both on physiology and disease (Ambros, 2004; Bushati and Cohen, 2007; Gangaraju and Lin, 2009; Mercer et al., 2009; Ponting et al., 2009; Wilusz et al., 2009; Berezikov, 2011; Lujambio and Lowe, 2012). Indeed, the number of ncRNAs per genome correlates far better with organism complexity than the number of coding genes, suggesting that RNA-based regulatory mechanisms are critical in the evolution of developmental complexity (Taft et al., 2007).

Regulatory ncRNAs can be divided into two classes based on their length: small and long ncRNAs (lncRNAs). Small ncRNAs comprise the short $(<200 \mathrm{nt})$ RNA species, such as smallinterfering RNAs (siRNAs, 19-23 nt), piwi-interacting RNAs (piRNAs, 26-30 nt), and microRNAs (miRNAs, 18-25 nt). lncRNAs comprise different types of transcripts, 100s to 1000s of nucleotides long, which are usually classified according to their genomic localization relative to the protein coding genes: sense, antisense, intronic, and intergenic ncRNAs.

\section{miRNAs: BIOGENESIS AND FUNCTIONS}

Since the discovery in 1993 of the first small regulatory RNAs, lin-4 and let-7, which control the timing of C. Elegans larval development (Lee et al., 1993; Reinhart et al., 2000), thousands of different miRNAs have been identified in different organisms, including plants, animals and viruses (Lagos-Quintana et al., 2001). According to the last release of the miRNA database (miRBase http://www.mirbase.org - release 21) 1881 precursor and 2588 mature miRNAs exist in the human genome (Kozomara and Griffiths-Jones, 2014).

The biogenesis of miRNAs is a multistep process (reviewed in $\mathrm{Ha}$ and Kim, 2014 and summarized in Figure 1). The canonical pathway consists of at least four steps: transcription, nuclear, and cytoplasmic processing, loading into RNAinduced silencing complex (RISC) and decay. Transcription of miRNAs usually involves RNA polymerase II (Pol II), meaning that miRNA genes share the transcriptional machinery of protein coding genes, including transcription factors, enhancers, and epigenetic regulation. The genomic organization of miRNA genes also influences their transcription. Intragenic miRNAs, which constitute $\sim 40-45 \%$ of all human miRNAs, are co-transcribed with their "host gene" and, thus, share the same transcriptional regulation. Conversely, intergenic miRNAs form independent transcriptional units (Garzon 


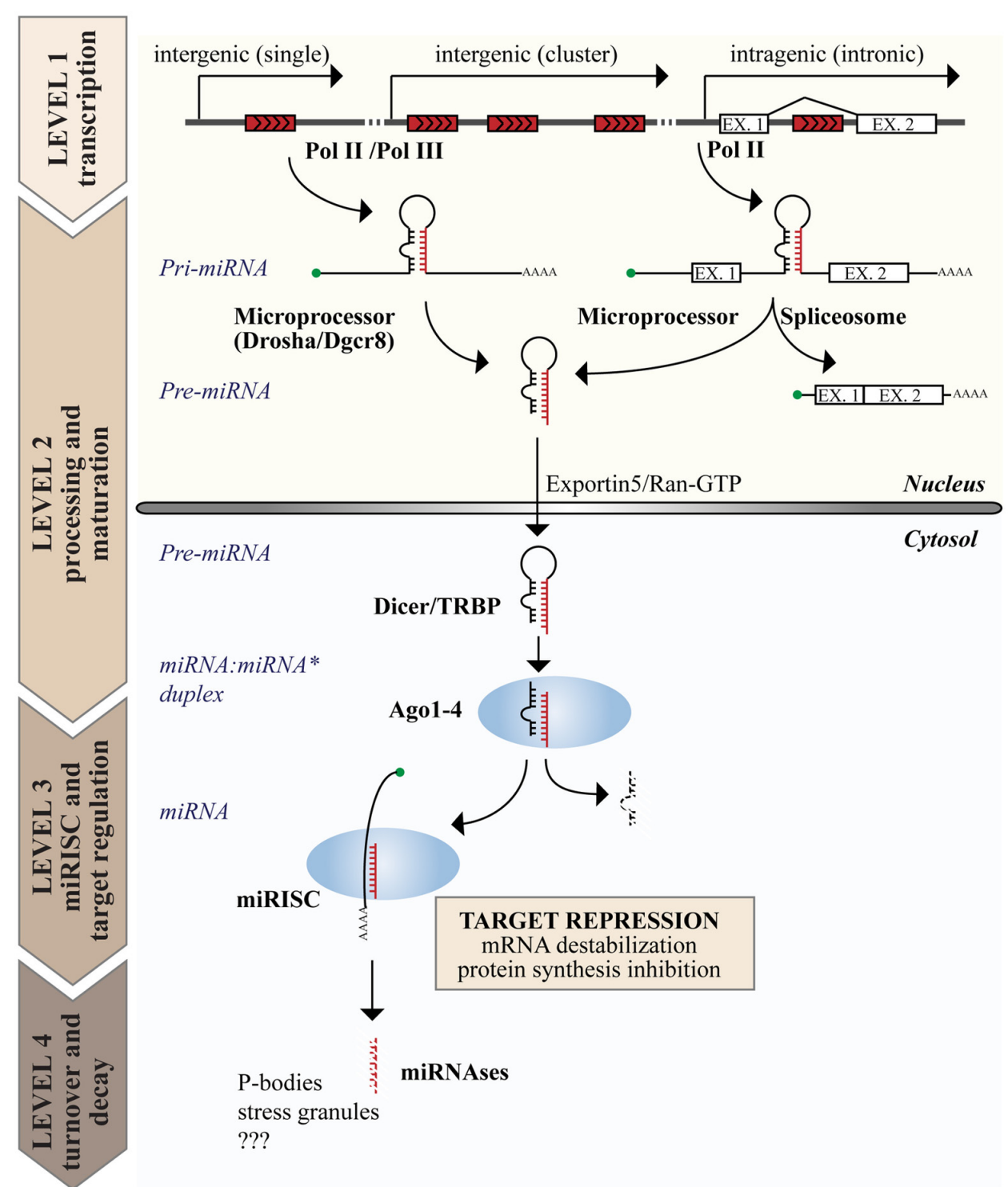

FIGURE 1 | Genome organization and biogenesis of microRNAs

(miRNAs). miRNA genes are interspersed in the genome with various possible locations as depicted on top. The figure summarizes the steps of the canonical miRNA biogenetic pathway, including the production of a primary transcript (pri-miRNA) by RNA polymerase II or III (Pol II or III), nuclear and cytoplasmic processing, loading into the miRISC complex, and the degradation of mature miRNAs. The function of miRNAs is exerted in the cytosol at the level of the miRISC, where miRNAs induce target gene repression by various mechanisms, including inhibition of protein synthesis and mRNA destabilization et al., 2009). Occasionally, multiple miRNAs are organized in a single transcriptional unit, named "miRNA cluster" (Lee et al., 2002).

The expression of miRNAs begins with a long primary transcript, called the primary miRNA (or "pri-miRNA"), which contains a stem-loop region for each encoded miRNA and can range in size from hundreds of nucleotides to 10 s of kilobases. Two processing events are required to generate the mature miRNA duplex, each generating an RNA molecule with a $5^{\prime}$ phosphate and a $\sim 2$ nt $3^{\prime}$ overhang (Han et al., 2006). The first occurs in the nucleus and is mediated by the Microprocessor complex, composed of the RNase III endonuclease DROSHA and the DiGeorge syndrome Critical Region 8 (DGCR8) protein, which recognizes dsRNA-ssRNA junction and directs the cleavage site 11 nt away (Denli etal., 2004; Gregory et al., 2004). This cleavage event produces an intermediate hairpin precursor molecule of 65-100 nt, called the "pre-miRNA," which is translocated from the nucleus to the cytoplasm by Exportin 5 and RAN-GTP (Lund et al., 2004). The second processing event occurs in the cytosol and is mediated by the RNase III endonuclease DICER in complex with the TAR RNA Binding Protein (TRBP; Bernstein etal., 2001). This last cleavage event generates the mature miRNA:miRNA* duplex (18-24 nt in length), which is immediately incorporated into the RISC, composed of 
Argonaute (AGO) proteins (Hammond et al., 2001; Mourelatos et al., 2002). However, only one strand of the duplex is retained in the RISC (the "guide" miRNA), while the other is discarded and degraded, resulting in a strong bias for guide strands in the miRNA pool (Khvorova et al., 2003; Schwarz et al., 2003). This miRNA maturation process is mainly regulated at the level of nuclear processing, and sequence determinants and auxiliary factors also contribute to its regulation (Auyeung et al., 2013; Mori et al., 2014).

There is evidence that a small proportion of miRNAs $(<1 \%)$ are produced by non-canonical mechanisms, including: Droshaindependent mechanisms (as in the case of "mirtrons"), in which mRNA splicing produces a small RNA hairpin thereby bypassing Drosha processing (Berezikov et al., 2007); and Dicer-independent mechanisms (as in the case of miR-451), in which a short stemloop is not loaded onto Dicer but directly processed by Ago2 (Yang et al., 2010).

Once loaded into the AGO-based complexes, miRNAs appear as rather stable molecules with long half lives (greater than $24 \mathrm{~h}$ ); however, scattered reports suggest that miRNAs could also undergo a rapid and regulated decay (Krol et al., 2010; Rissland et al., 2011; Ruegger and Grosshans, 2012). Although miRNA biogenesis has been studied for 20 years, the mechanisms of miRNA degradation are largely obscure, in particular in higher organisms. At least two possible mechanisms have been proposed. The first involves the enzymatic activity of specific nucleases ("miRNases"), such as the plant SNDs (Wu and Belasco, 2008) and the worm $5^{\prime}$-to- $3^{\prime}$ exoribonucleases XRN1 and XRN2 (Chatterjee and Grosshans, 2009). The second is a target-dependent mechanism, in which miRNA turnover is mediated by the interaction with mRNA targets that promote miRNA unloading from AGO and degradation (Baccarini et al., 2011; Ruegger and Grosshans, 2012; De et al., 2013).

Typically, miRNAs exert specific biological actions by interfering with a key regulator (e.g., a transcription factor) responsible for a defined phenotype (the "hub target" mechanism) or through the coordinated action on multiple target genes that belong to the same pathway (the "multiple targets" mechanism; Hausser and Zavolan, 2014). The interaction between miRNAs and their mRNA targets occurs in the cytosol at the level of the RISC and is directed by Watson-Crick base-pairing with the "miRNA Responsive Element" (MRE), usually located in the $3^{\prime}$-Untranslated Region ( $3^{\prime}$-UTR) of the target mRNA (Bartel, 2009). The critical determinant of miRNA specificity is a region located at the $5^{\prime}$ end of the miRNA in positions $2-8$, called the "seed" sequence, which defines the target specificity of any mature miRNA. As the extent of miRNA:mRNA interaction is limited, 100s or even thousands of different genes are potential miRNA targets. These targets can be partially inferred with prediction algorithms that search in the $3^{\prime}$ UTR of protein coding genes for the presence of MREs (i.e., miRanda, Targetscan, Pictar, DIANA microT, and RNAhybrid; Thomas etal., 2010). However, none of these algorithms are completely accurate, especially as some miRNA targets rely on "seedless" interactions.

Target down-modulation occurs through multiple mechanisms, including translational repression (inhibition of cap recognition or 605 recruitment, ribosome drop-off, and increase of termination efficiency) and/or mRNA destabilization (deadenylation or decapping). Rarely, in cases of perfect or near-perfect complementarity, miRNAs can function as siRNAs, inducing mRNA degradation (Carthew and Sontheimer, 2009).

\section{IncRNAs: BIOGENESIS AND FUNCTIONS}

Long ncRNAs consist of a heterogeneous class of ncRNAs, operationally defined as any RNA molecule with low coding potential and a size greater than $200 \mathrm{nt}$ : a cut-off arbitrarily based on RNA purification protocols (Kapranov et al., 2007). They can be classified, according to their genomic organization relative to protein-coding transcripts (Rinn and Chang, 2012), as: (i) overlapping transcripts (sense or antisense, promoter-/intronic-/3'UTRassociated); (ii) divergent transcripts, which share the same promoter with coding genes, but are transcribed in the opposite direction; (iii) intergenic transcripts (lincRNAs), which are located in gene-desert regions (see Figure 2).

Genetic loci of lncRNAs are similar to those of mRNAs, sharing the same transcriptional machinery (Pol II), same layers of epigenetic regulation (such as histone-modification profiles) and splicing signals (Guttman et al., 2009; Derrien et al., 2012). Almost half of the lncRNAs are also capped and polyadenylated. LncRNAs are frequently bi-exonic and localize predominantly in the nucleus. Their expression is highly cell-type specific, but on average to a lesser extent than protein-coding genes (Ravasi et al., 2006; Cabili et al., 2011; Djebali et al., 2012). Although most lncRNAs have very low translational potential, ribosome profiling (a technique that uses deep sequencing of ribosome-protected fragments to monitor in vivo translation) revealed that many lncRNAs can be engaged by ribosomes, and some have the potential of producing small peptides ( $<100$ amino acids), whose biological significance is completely unknown (Ingolia et al., 2011; Bazzini et al., 2014).

Identification of lncRNAs is not a trivial task, but requires unbiased RNA detection methods, precise mapping in the genome within regions distinct from those occupied by coding transcripts, and analysis of protein-coding potential. Current approaches applied to lncRNA identification include: (i) tiling microarrays; (ii) unbiased RNA cloning techniques (SAGE and CAGE); (iii) massive parallel sequencing of transcripts (RNA-sequencing, RNA-seq); and (iv) chromatin immunoprecipitation combined with DNA sequencing (ChIP-seq). The latter approach is based on the identification of chromatin domains associated with active transcription, such as those with histone $\mathrm{H} 3$ lysine 4 trimethylation ( $\mathrm{H} 3 \mathrm{~K} 4 \mathrm{me} 3)$ at the promoter, and histone $\mathrm{H} 3$ lysine 36 trimethylation ( $\mathrm{H} 3 \mathrm{~K} 36 \mathrm{me} 3$ ) on the transcribed gene body [known as "H3 K4-K63 domains," (Mikkelsen et al., 2007; Guttman etal., 2009)]. Mapping in the genome is easier for lncRNAs that are located in gene-desert regions (intergenic - lincRNAs), while strand-specific reactions (strand-specific RT-qPCR or sequencing) are needed to identify overlapping lncRNAs. The coding potential of IncRNAs is typically assessed by searching for any open reading frame (ORF) that match known proteins or domains. However, this approach could miss small ORFs or newly evolved proteins. Alternatively, methods that use the codon substitution frequency to determine the likelihood that a sequence is protein coding can be exploited (Lin et al., 2011). 


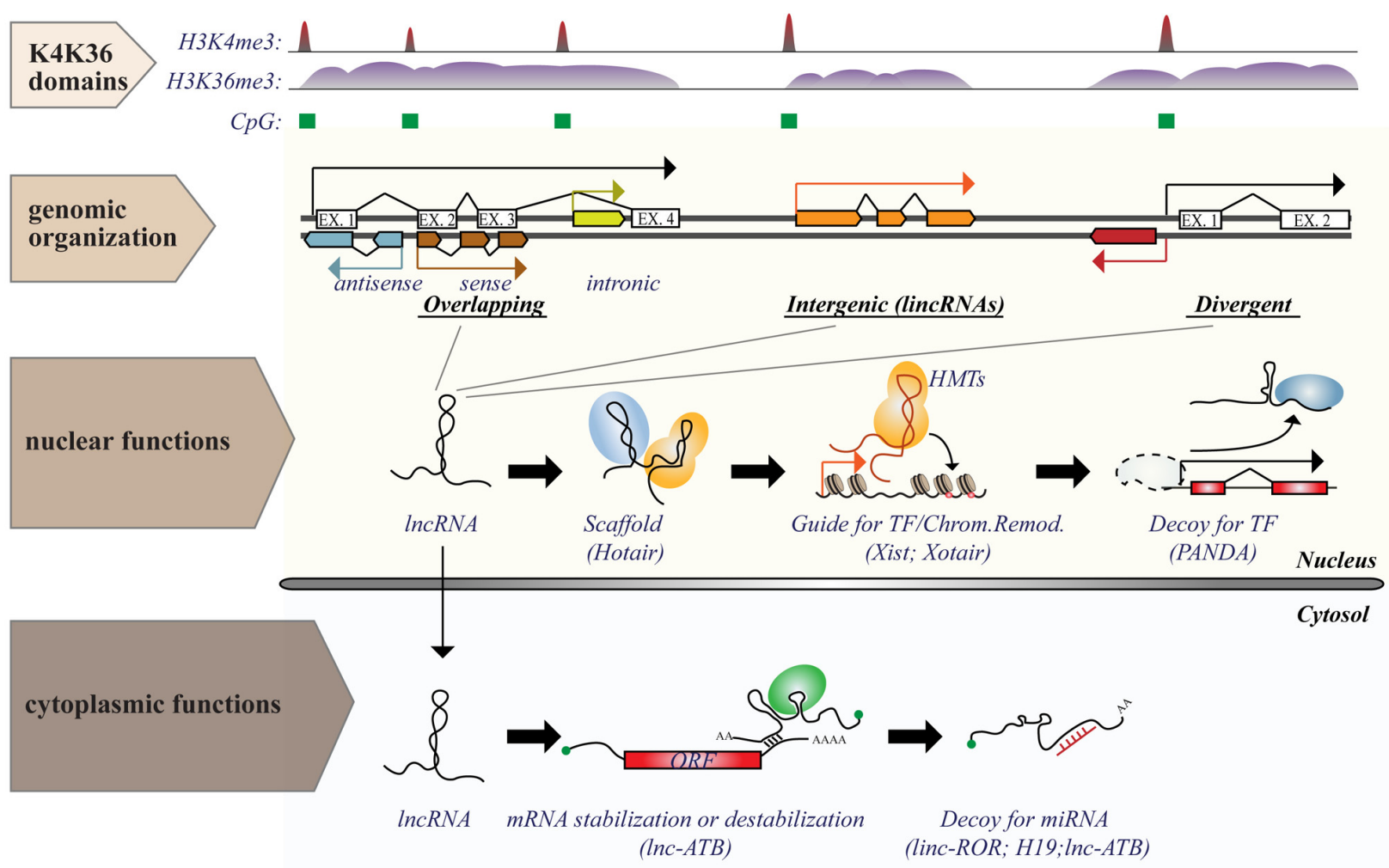

FIGURE 2 | Genomic organization and functions of long ncRNAs (IncRNAs). IncRNA genes are interspersed in the genome in various possible locations in relation to protein coding transcripts, such as (i) overlapping; (ii) intergenic; or (iii) divergent transcripts. Transcription of IncRNAs follows the same rules as for protein coding genes and is executed by RNA Pol II. Genomic features associated with transcription [such as $\mathrm{CpG}$ island (green boxes) or histone marks (histone $\mathrm{H} 3$ "K4K36 domains")] provide a useful strategy to identify expressed IncRNAs. Functions of IncRNAs are executed by multiple modes of action and can occur both in the nucleus and in the cytosol. The figure shows some examples of nuclear or cytoplasmic functions of some known IncRNAs.
In contrast to miRNAs, which are highly conserved and mainly involved in negative regulation of gene expression at the post-transcriptional level, lncRNAs are poorly conserved and could regulate gene expression (either positively or negatively) at numerous levels by a variety of mechanisms (summarized in Figure 2), some of which are yet to be characterized (Cech and Steitz, 2014). Expression of lncRNAs occurs at a very precise time and/or developmental stage, suggesting a general role as "molecular signals" that integrate developmental cues or respond to different stimuli (Wang and Chang, 2011). Due to their purely transcriptional nature, lncRNAs could function immediately after transcription (with no need for protein translation) and act either locally, by affecting the expression of neighboring genes (cis-acting), such as during imprinting, or at distant sites (trans-acting; Ebisuya et al., 2008; Guttman and Rinn, 2012). Even in the absence of a regulatory function, the transcription of lncRNAs could serve as a signal per se, interfering or fostering the expression of neighboring/overlapping genes, as in the case of the lncRNAs, AIR, and XIST (Rinn and Chang, 2012).

The regulatory function of lncRNAs could also depend on their interaction with other molecules. In this case, lncRNAs act as "decoys" that titrate away transcription factors, splicing proteins or even miRNAs, thus relieving the activation/inhibition on target genes. Examples of such lncRNAs include TERRA, PANDA, PTENP, linc-MD1, and linc-ATB. Alternatively, lncRNAs could function as a "guide," directing ribonucleoproteic complexes to specific loci to control gene expression locally (on neighboring genes) or at distant sites. Lastly, lncRNAs could function as scaffolds (e.g., HOTAIR - HOX antisense intergenic RNA), upon which other molecular components are assembled, bringing together independent functions/activities (Mercer et al., 2009; Ponting et al., 2009; Wang and Chang, 2011).

\section{NORMAL AND CANCER MAMMARY STEM CELLS THE STEM CELL COMPARTMENT IN THE NORMAL MAMMARY GLAND}

The mammary gland is a glandular epithelium composed of milk-secreting hollow cavities, named alveoli, joined together by ducts to form groups termed lobules. Ducts also connect different lobules and eventually merge into the lactiferous duct that opens into the nipple. Mature cells that compose the mammary epithelium include luminal cells, in the inner layer of the mammary gland, and myoepithelial cells, located in the outer layer of the gland. The latter cells make contact with the basement membrane, physically sustaining the organ and providing the contractile force needed during lactation (Figure 3). 

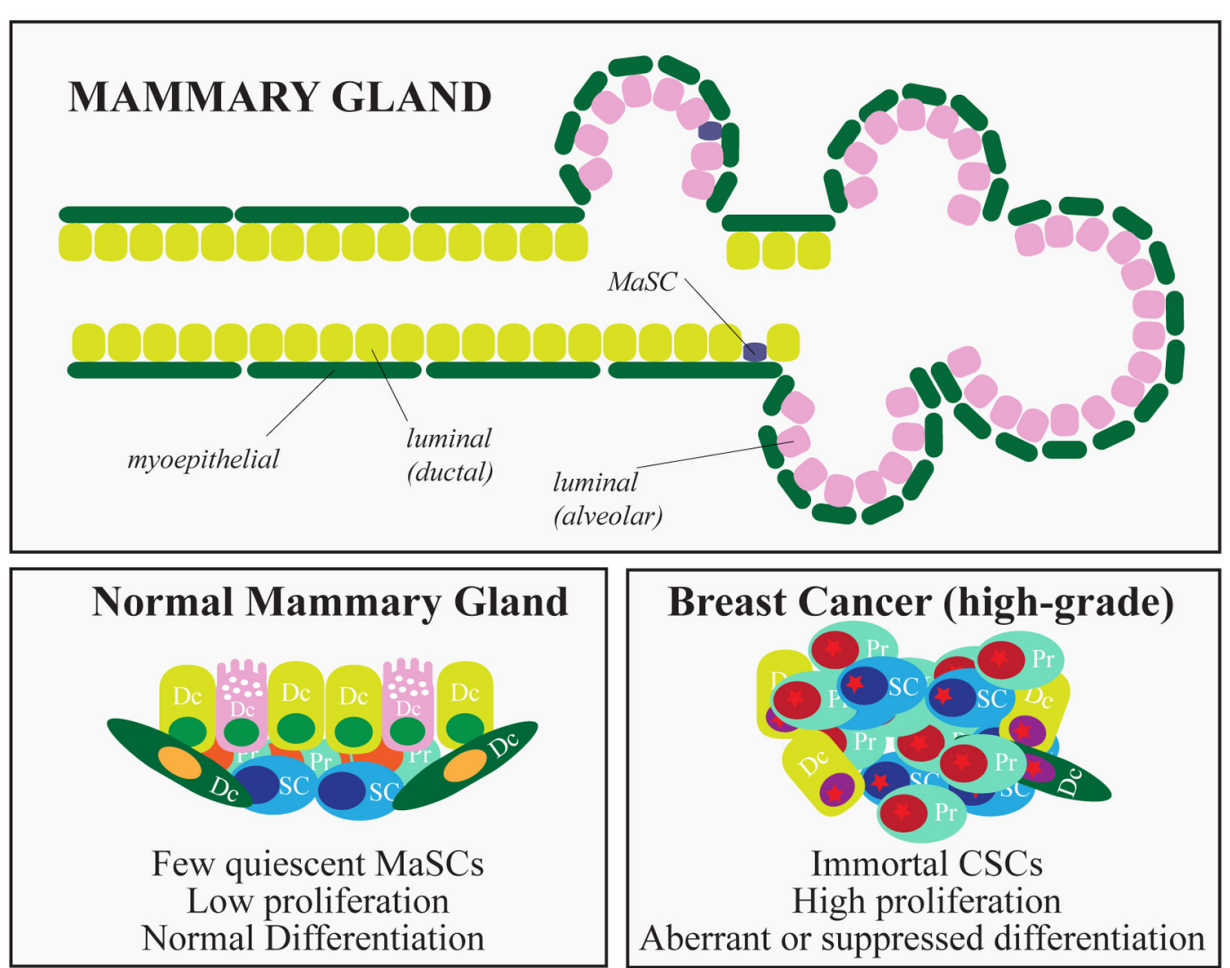

FIGURE 3 | Hierarchical organization of the mammary gland and breast cancer subtypes. The figure depicts the epithelial components of the mammary gland. In the lower part, the characteristics of normal and cancer stem cells are summarized. (SC, stem cells; PC, progenitors; DC, differentiated cells).

The mammary gland is a highly dynamic organ that undergoes important morphogenetic changes during adult development (puberty) or during pregnancy-lactation and involution (Visvader and Stingl, 2014). Remarkably, the mammary gland maintains the ability to perform structural remodeling for several cycles, suggesting the existence of a reservoir of adult stem cells (SCs) able to sustain multiple rounds of pregnancy-lactationinvolution and to generate all the cellular lineages that compose the gland.

Pioneering experiments in mice, using transplantation of entire sections of the gland (Deome et al., 1959) or isolated epithelial cells (Stingl et al., 2006), proved the existence of a multipotent population of rare cells able to reconstitute the entire organ: normal mammary stem cells (MaSCs). This in vivo reconstitution assay has become the gold standard in MaSC identification (Shackleton et al., 2006; Stingl et al., 2006; Cicalese et al., 2009) and has allowed the evaluation of mammary repopulating units (MRUs, functionally synonymous with MaSCs) in defined cellular subsets transplanted at limiting dilution, as a quantitative measure of MaSC abundance (Visvader, 2009). Lineage tracing experiments and reporter genes have helped to verify the clonality of mammary outgrowths, suggesting that unipotent and multipotent MaSCs coexist, endowed with the ability to repopulate the mammary gland by generating the different luminal and basal mammary lineages (Kordon and Smith, 1998; Van Keymeulen et al., 2011; Rios et al., 2014; Wang et al., 2014). Similarly to most adult SCs, MaSCs possess a number of defining characteristics: (i) multi-lineage differentiation potential (they can generate both luminal and basal lineages); (ii) ability to self-renew, usually through an asymmetric type of cell division, which generates one daughter SC and one progenitor, and maintains homeostasis of the SC pool; (iii) quiescence (or slow rate of division), unless activated, as occurs during pregnancy or lactation; and (iv) ability to withstand anoikis, surviving in anchorage-independent conditions.

An important advance in MaSC biology derived from the work of Dontu et al. (2003), who developed an in vitro methodology, the mammosphere assay, which maintains MaSCs in an undifferentiated condition and facilitates the study of self-renewal mechanisms. The assay exploits the ability of SCs to grow in anchorage independent conditions as clonal spheroids, composed of quiescent SCs, progenitors and somewhat differentiated cells. Under these culture conditions, MaSCs maintain their fundamental properties (self-renewal and multilineage differentiation potential) and can recapitulate mammary outgrowths when transplanted in vivo (Dontu et al., 2003).

\section{BREAST CANCER AND MAMMARY CANCER STEM CELLS}

Breast cancer is the main disease of the mammary gland and one of the most common life-threatening diseases for women in Western countries (DeSantis et al., 2014). Thanks to the advent of genomewide approaches, both oncologists and biologists have realized that breast cancer is a quite heterogeneous disease, and have attempted to classify tumors according to their molecular characteristics. This 
has led to a classification of breast tumors into at least five different molecular subtypes, based on their peculiar transcriptional profile: Luminal A, Luminal B, Her2-positive, Claudin-low, and Basal tumors (Perou et al., 2000; Sorlie et al., 2001; Sotiriou et al., 2003; Lehmann et al., 2011; Prat and Perou, 2011). These findings have revealed the molecular basis for breast tumor heterogeneity and suggested that different subtypes should be treated as different diseases, with tailored treatments and therapeutic strategies (Sotiriou and Pusztai, 2009).

As morphogenesis and homeostasis of adult tissues are sustained by SCs, it has been hypothesized that a similar mechanism might fuel the growth of tumors, relying on the existence of subpopulations of cancer cells with stem-like properties (cancer stem cells - CSCs, Medema, 2013). The CSC hypothesis implies that tumors are hierarchically organized like normal tissues, with a subset of tumor cells at the top of the hierarchy possessing the ability to self-renew and to differentiate, albeit aberrantly. Breast cancer was one of the first solid malignancies in which CSCs were identified and characterized, mostly immunophenotypically as $\mathrm{lin}^{-} / \mathrm{CD} 44^{+} / \mathrm{CD} 24^{-}$cells (Al-Hajj, 2003). Mammary CSCs were the only cells able to sustain tumor growth in NOD/SCID mice, whereas cells that did not express the CSC markers were nontumorigenic (Al-Hajj, 2003). Mammary CSCs are also considered to be responsible for relapse and metastasis. This contention is based on multiple observations: (i) poorly differentiated, more aggressive breast cancers tend to be CSC-rich, compared to more highly differentiated, less aggressive, CSC-poor breast tumors (Pece et al., 2010); (ii) mammary CSCs are relatively resistant to both radiation treatments and cytotoxic chemotherapy in vitro and in vivo (Liu and Wicha, 2010), a property reminiscent of the intrinsic ability of MaSCs to withstand genotoxic stress; and, finally, (iii) the proportion of cells with CSC properties is typically increased after conventional therapies (Li et al., 2008; Creighton et al., 2009).

Recent research has provided evidence of functional plasticity within the SC compartment, suggesting that CSCs should not be considered as a fixed entity, solely derived from the transformation of a normal SC, but rather as the result of the acquisition of "stemness" properties by tumor cells (Gupta et al., 2011). In particular, in cancer cell populations' bidirectional interconversion between CSCs and non-CSCs occurs under certain conditions (Roesch et al., 2010; Chaffer et al., 2011; Gupta et al., 2011). This plasticity is not a universal property of cancer cells and it is appears to be associated with certain tumor subtypes, such as breast basal carcinomas. Although it is currently unclear how frequently the interconversion between CSCs and non-CSCs occurs in vivo, cell state dynamics are dependent on external (i.e., microenvironment) and internal (i.e., genetic) cues, and rely on the same epigenetic, transcriptional and post-transcriptional mechanisms that control "stemness" in normal SCs (Roesch et al., 2010; Chaffer et al., 2011; Gupta et al., 2011).

One such mechanism is the epithelial-to-mesenchymal transition (EMT), a reversible transcriptional program that is physiologically activated during embryogenesis, allowing partial or complete transition of cells from an epithelial to a mesenchymal state (Thiery et al., 2009). Pathways leading to EMT are activated by specific stimuli, such as transforming growth factor beta (TGF$\beta$ ) or fibroblast growth factor (FGF), through the stimulation of EMT transcription factors (EMT-TFs), such as members of the snail family (SNAIL1/2), bHLH family (TWIST), and ZFH family (ZEB1 and ZEB2), which repress epithelial gene expression and foster the establishment of a motile and invasive mesenchymal phenotype (Thiery and Sleeman, 2006). EMT program(s) have been frequently associated with cancer progression, metastasis and acquisition of SC-traits (Thiery et al., 2009; Hanahan and Weinberg, 2011). In breast cells, the expression of EMT-TFs, such as TWIST and SNAIL, induces mesenchymal and stem-related markers, increases mammosphere formation, expands the CSC population $\left(\mathrm{CD} 44^{+} / \mathrm{CD} 24^{-}\right)$and induces tumorigenesis (Mani et al., 2008).

Of note, both mouse (CD49f $\mathrm{f}^{\text {high }} / \mathrm{CD} 24^{\text {med }}$ ) and human MaSCs (CD44 $\left.4^{\text {high }} / \mathrm{CD} 24^{\text {low }}\right)$ express markers associated with EMT, such as N-cadherin, Vimentin, SNAIL1/2, and SLUG (Mani et al., 2008). In mouse models, the expression of the EMT-TF SLUG is sufficient to reprogram luminal progenitor cells $\left(\mathrm{CD}^{+} 1^{+}\right)$to fully functional MaSCs suggesting that a certain degree of plasticity between SC and progenitor states also exists in the normal breast epithelium (Guo et al., 2012). Indeed, interconversion from an epithelial to a mesenchymal/stem-like state has been also observed in human mammary epithelial cells (Chaffer et al., 2011, 2013). In this context, the maintenance of self-renewal properties and protection from spontaneous differentiation is achieved through autocrine and paracrine signals, which involves TGF- $\beta$ canonical and noncanonical Wnt pathway activation and EMT-TFs (SLUG, TWIST, ZEB1/2; Scheel et al., 2011).

Finally, and of relevance to the subject of this review, several ncRNAs have been associated with EMT in the breast gland, frequently acting together, in concert with chromatin regulators (CRs) and TFs. Relevant examples are miRNAs of the miR-200 family, miR-205, miR-7, miR-22, and some lncRNAs, including HOTAIR, linc-RoR, H19, and lncRNA-ATB (discussed below).

\section{CELL FATE SPECIFICATION BY miRNAs AND IncRNAs OCCURS BY INTEGRATING MULTIPLE SIGNALING PATHWAYS INVOLVED IN SC AND CSC BIOLOGY}

As previously mentioned, the activity of ncRNAs, either miRNA or lncRNAs, is integrated with signaling networks and the transcriptional framework, thus, generating complex circuits that control cell fate and differentiation. Hereafter, we will discuss the current knowledge of the involvement of ncRNAs in the biology of MaSCs and of mammary CSCs (summarized in Tables 1 and 2, and schematized in Figure 4).

\section{LET-7 FAMILY AND IL6/STAT3 CIRCUITRY}

The first report showing the involvement of a miRNA in mammary CSCs was in 2007, when Yu et al. (2007) described their observation that let-7 levels were markedly reduced in tumor-initiating cells (TICs, defined as $\operatorname{lin}^{-} / \mathrm{CD} 44^{+} / \mathrm{CD} 24^{-}$, and operationally equal to CSCs) compared to their non tumorigenic counterparts. To identify miRNAs potentially involved in the control of CSC biology, they used a derivative of the SK-BR-3 breast cancer cell line, named SK-3rd, obtained by serial passaging of the original cell line in NOD/SCID mice treated with chemotherapy. As 
Table 1 | List of microRNAs (miRNAs) and long ncRNAs (IncRNAs) associated with normal breast stem cells (SCs).

\begin{tabular}{|c|c|c|c|c|c|c|}
\hline ncRNAs & Cell Type & Function & $\begin{array}{l}\text { Signaling } \\
\text { upstream }\end{array}$ & $\begin{array}{l}\text { Signaling } \\
\text { downstream }\end{array}$ & Target genes & Reference \\
\hline Let-7 & $\begin{array}{l}\text { Normal breast cells } \\
\text { (MCF10A) } \\
\text { Human }\end{array}$ & $\begin{array}{l}\text { Inhibition of } \\
\text { self-renewal/promoter } \\
\text { of differentiation }\end{array}$ & $\mathrm{SRC/IL-6/NF-kB}$ & $\begin{array}{l}\text { LIN28/Let- } \\
\text { 7/STAT3 }\end{array}$ & & Iliopoulos et al. (2009) \\
\hline $\begin{array}{l}\text { Let-7/miR- } \\
\text { 205/miR-22 }\end{array}$ & $\begin{array}{l}\text { Mammary gland } \\
\text { progenitors } \\
\text { (Comma-D } \beta \text { ) Mouse }\end{array}$ & $\begin{array}{l}\text { Inhibition of } \\
\text { self-renewal by let-7 }\end{array}$ & & & & Ibarra etal. (2007) \\
\hline miR-205 & $\begin{array}{l}\text { Breast epithelial cells } \\
\text { (HMEC) } \\
\text { Human }\end{array}$ & Inhibition of EMT & JAG1/NOTCH2 & Hes1/ZEB1 & ZEB1/NOTCH2 & Chao et al. (2014) \\
\hline miR-200c & $\begin{array}{l}\text { Human primary } \\
\text { breast SCs } \\
\left(\mathrm{CD} 44^{+} / \mathrm{CD} 24^{-}\right)\end{array}$ & $\begin{array}{l}\text { Inhibition of } \\
\text { self-renewal }\end{array}$ & & & $\mathrm{BMI} / \mathrm{PRC} 1$ & Shimono etal. (2009) \\
\hline miR-22 & $\begin{array}{l}\text { Normal breast cells } \\
\text { (MCF10A - HMEC) } \\
\text { and Mouse models }\end{array}$ & $\begin{array}{l}\text { Promoter of EMT and } \\
\text { stemness }\end{array}$ & & ZEB1-ZEB2 & $\begin{array}{l}\text { TET and miR-200 } \\
\text { inhibition }\end{array}$ & Song etal. (2013) \\
\hline $\begin{array}{l}\text { miR-205/-200 } \\
\text { family }\end{array}$ & MDCK cells & $\begin{array}{l}\text { Maintenance of the } \\
\text { epithelial state }\end{array}$ & TGF- $\beta$ & & ZEB1-ZEB2 & Gregory et al. (2008) \\
\hline
\end{tabular}

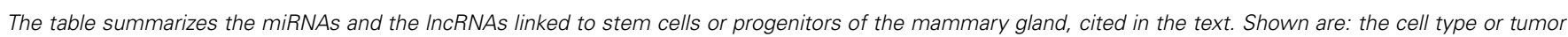

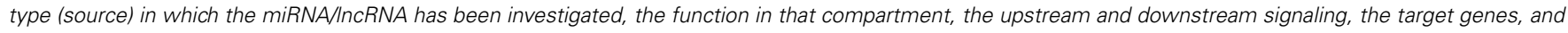
the appropriate references.

chemotherapy typically increases the proportion of CSCs within breast tumors, the SK-3rd derivative had an increased proportion of CSCs compared with the parental line, as assessed by the mammosphere assay, cell surface marker expression $\left(\mathrm{CD} 44^{+} / \mathrm{CD} 24^{-}\right)$ and in vivo xenotransplantation assays. Several members of the let-7 family (plus other miRNAs, such as the miR-200 family) were depleted in SK-3rd cells as compared to the parental cells. Importantly, the same miRNAs were downregulated in CSCs from clinical breast cancer samples ( $\mathrm{lin}^{-} / \mathrm{CD} 44^{+} / \mathrm{CD} 24^{-}$) compared to their non-tumorigenic counterparts. The overexpression of let-7 in mammary CSCs caused a striking impairment in proliferation, mammosphere-forming ability, and tumor formation and metastasis in vivo. Mechanistically, the levels of let-7 inversely correlated with those of two of its direct targets, H-RAS and HMGA2, which are involved in SC self-renewal and multipotency regulation. Silencing of these two targets in mammary CSCs partially recapitulated the effects of let-7 overexpression, suggesting that the repression of 'stemness' traits by let-7 is, in part, mediated by the repression of H-RAS and HMGA2 (Yu et al., 2007).

In the mouse, members of the let-7 family were shown to be expressed at low levels in self-renewing progenitors $\left(\mathrm{ALDH}^{+} / \mathrm{Sca}-\right.$ $1^{+}$) and induced upon differentiation, suggesting that low levels of let-7 mark the self-renewal compartment and could be used to prospectively isolate MaSCs (Ibarra et al., 2007). Accordingly, the let-7 family emerged as the most induced group of miRNAs upon estradiol treatment in human luminal cells (MCF-7; Bhat-Nakshatri et al., 2009).

Several independent studies further suggested that miRNAs of this family are implicated in the self-renewal of CSCs in breast and other cancers, by multiple mechanisms. One of these mechanisms involves the pluripotency gene known as LIN28/LIN28B, which inhibits the function of let-7 by interfering with its biogenesis (Piskounova et al., 2011). LIN28 is frequently overexpressed and associated with advanced malignancy in multiple cancer types (Viswanathan et al., 2009). In breast cancer, LIN28 expression confers CSC-traits and impinges on signaling mechanisms involved in self-renewal of normal and cancer SCs, such as the Wnt/beta-catenin pathway, NF-kB signaling, and inflammatory cytokine signaling (Iliopoulos et al., 2009; Cai et al., 2013). Members of the interleukin-6 (IL-6) family, which are induced in a paracrine/autocrine fashion in breast cancer, mediate the activation of the Janus Kinase 2 (JAK2) and of the signal-transducer and transcription factor 3 (STAT3) promoting the expansion of mammary CSCs (Marotta et al., 2011; Yu et al., 2014). The IL-6/STAT3 axis can induce LIN28 expression, which in turn inhibits let-7 activity, thus generating a positive feedback loop (let-7 targets IL-6) that confers SC traits 
Table 2 | List of miRNAs and IncRNAs associated with breast cancer stem cells (CSCs).

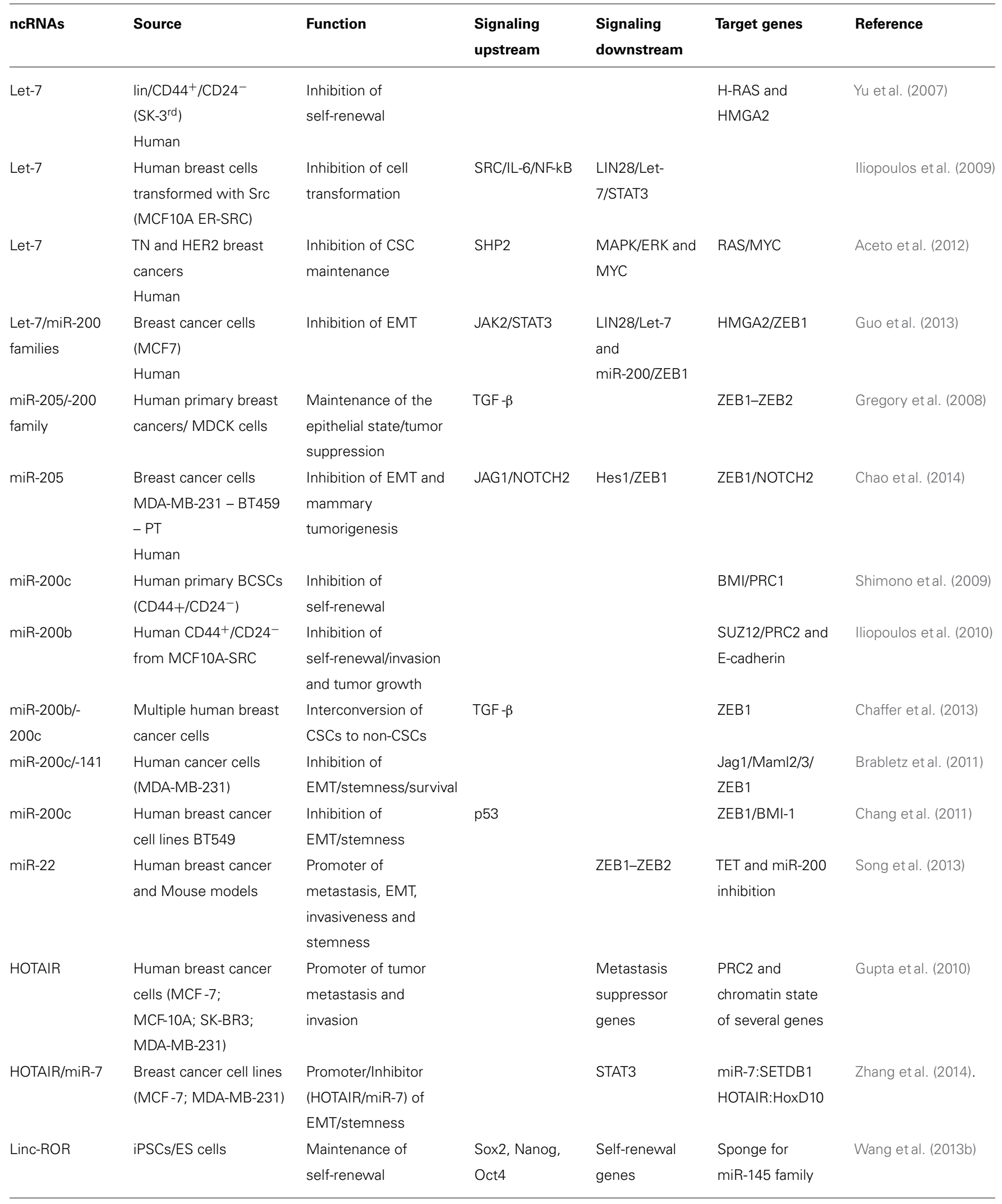


Table 2 | Continued

\begin{tabular}{|c|c|c|c|c|c|c|}
\hline ncRNAs & Source & Function & $\begin{array}{l}\text { Signaling } \\
\text { upstream }\end{array}$ & $\begin{array}{l}\text { Signaling } \\
\text { downstream }\end{array}$ & Target genes & Reference \\
\hline Linc-ROR & $\begin{array}{l}\text { Multiple human } \\
\text { breast cancer cells }\end{array}$ & $\begin{array}{l}\text { Promoter of } \\
\text { EMT/stem-like } \\
\text { features }\end{array}$ & & & $\begin{array}{l}\text { Sponge for } \\
\text { miR-205 }\end{array}$ & Hou et al. (2014) \\
\hline Lnc-H19 & $\begin{array}{l}\text { Muscle cells and } \\
\text { cancer cells }\end{array}$ & $\begin{array}{l}\text { Promoter of muscle } \\
\text { differentiation }\end{array}$ & & $\begin{array}{l}\text { Differentiation } \\
\text { genes/let-7 } \\
\text { targets }\end{array}$ & $\begin{array}{l}\text { Sponge for let-7 } \\
\text { family }\end{array}$ & Kallen et al. (2013) \\
\hline Lnc-H19/miR-675 & $\begin{array}{l}\text { Human breast cancer } \\
\text { and cell lines } \\
\text { (MDA-MB-468) }\end{array}$ & $\begin{array}{l}\text { EMT/promoter of } \\
\text { tumor metastasis }\end{array}$ & $\begin{array}{l}\text { TGF }-\beta \\
\text { hypoxia/HGF } \\
\text { /SF }\end{array}$ & PI3K/AKT/Slug & E-cadherin & Matouk etal. (2007) \\
\hline Lnc-ATB & $\begin{array}{l}\text { Hepatocellular } \\
\text { carcinomas and } \\
\text { Human Breast cancer } \\
\text { cells (MCF-7) }\end{array}$ & $\begin{array}{l}\text { EMT/promoter of } \\
\text { tumor metastasis }\end{array}$ & TGF- $\beta / / L-11$ & $\begin{array}{l}\text { ZEB1- } \\
\text { ZEB2/STAT3 }\end{array}$ & $\begin{array}{l}\text { Sponge for } \\
\text { miR-200 family }\end{array}$ & Yuan et al. (2014) \\
\hline
\end{tabular}

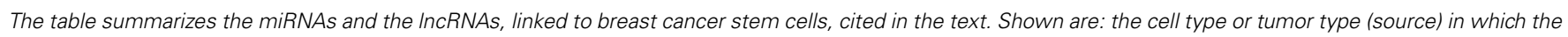
IncRNA has been investigated, the function in that compartment, the upstream and downstream signaling, the target genes and the appropriate references.

to mammary epithelial cells (Iliopoulos et al., 2009; Guo et al., 2013).

A similar loop is also operational downstream of the Src-homology 2 domain-containing phosphatase SHP2: a proteintyrosine phosphatase encoded by the PTPN11 locus. SHP2 is a transducer of RTK and cytokine-receptor signaling that promotes breast cancer progression and a CSC-phenotype in ER-negative cancers (Aceto et al., 2012). In this case, a signaling cascade that involves the mitogen-activated protein kinase (MAPK)/extracellular signal-related kinase (ERK) pathway and the MYC-oncogene is activated by SHP2 and sustained through let-7 downregulation. Indeed, let-7 targets multiple genes, including RAS and MYC, which feedback on ERKs and LIN28, respectively, thus creating a loop that maintains CSCs and fosters metastasis in HER2+ and triple-negative breast cancers (Aceto et al., 2012).

\section{THE H19 IncRNA AND BREAST CANCER METASTASIS}

Human H19 was the first lncRNA with no coding potential to be described, opening the door to the so-called "noncoding revolution" (Brannan et al., 1990). The H19 gene belongs to a conserved imprinted region on human chromosome 11, located near the insulin-like growth factor 2 (IGF2) gene, and encodes a $2.3 \mathrm{~kb}$ long, cytoplasmic, capped, and polyadenylated ncRNA that functions primarily in the epigenetic silencing of the IGF2 gene (Gabory etal., 2010). H19 is strongly induced during embryogenesis and selectively expressed by the maternally inherited chromosome, with the function of silencing in cis the maternal IGF2 allele, thereby allowing selective expression of the paternal allele (Bartolomei et al., 1991; Gabory et al., 2010).

In adult tissues, H19 expression is retained in muscles (skeletal muscles and the heart), or is suddenly activated in cancers, where it is believed to act mainly as an oncogene (Matouk et al.,
2007; Gabory et al., 2010). H19 functions in the adult are linked to miRNA circuits: H19 RNA is the precursor of miR-675, which is encoded in its first exon and involved in muscle development and regulation of EMT (Cai and Cullen, 2007; Matouk et al., 2014). Furthermore, H19 acts as a "decoy" for miRNAs of the let-7 family during muscle differentiation (Kallen et al., 2013). By this mechanism, the expression of $\mathrm{H} 19$ relieves the repression on endogenous let-7 targets, such as HMGA2 and DICER, potentially contributing to the onset of the transformed phenotype (Kallen et al., 2013). Indeed, H19 expression is high in some cancers, including breast carcinomas, where it is associated with metastasis and the acquisition of EMT traits (Matouk et al., 2014). Several mechanisms can induce H19 expression in breast cancer cells, including: (i) activation from within the cell by upregulation of E2F1 (Berteaux et al., 2005), c-MYC (Barsyte-Lovejoy et al., 2006), or the loss of the tumor suppressor p53 (Dugimont et al., 1998); or (ii) activation by external stimuli, such as TGF- $\beta$, hypoxia, and HGF/SF. In this context, high levels of H19 could promote the loss of E-cadherin and the upregulation of the EMT-inducer SLUG to reinforce the mesenchymal state, through as yet an unknown mechanism that implicates both miR-675 and let-7 (Matouk et al., 2014).

\section{THE miR-200 FAMILY IN BETWEEN EMT AND CHROMATIN REGULATION}

In human primary samples, Shimono et al. (2009) identified a signature of 37 miRNAs differentially expressed between mammary CSCs and their non-tumorigenic counterparts. In particular, several members of the miR-200 family were found to be downregulated in mammary CSCs. This family comprises five members, which are organized in two conserved genomic clusters, one containing miR-200b, -200a, and -429 and the other encompassing miR-200c and miR-141 (Figure 4). miRNAs of this family were also found to be downregulated in MaSCs isolated by flow cytometry (lin $\left.{ }^{-} / \mathrm{CD} 49 \mathrm{f}^{\text {high }} / \mathrm{CD} 24^{\text {med }} / \mathrm{CD} 29^{\text {high }}\right)$ from the 


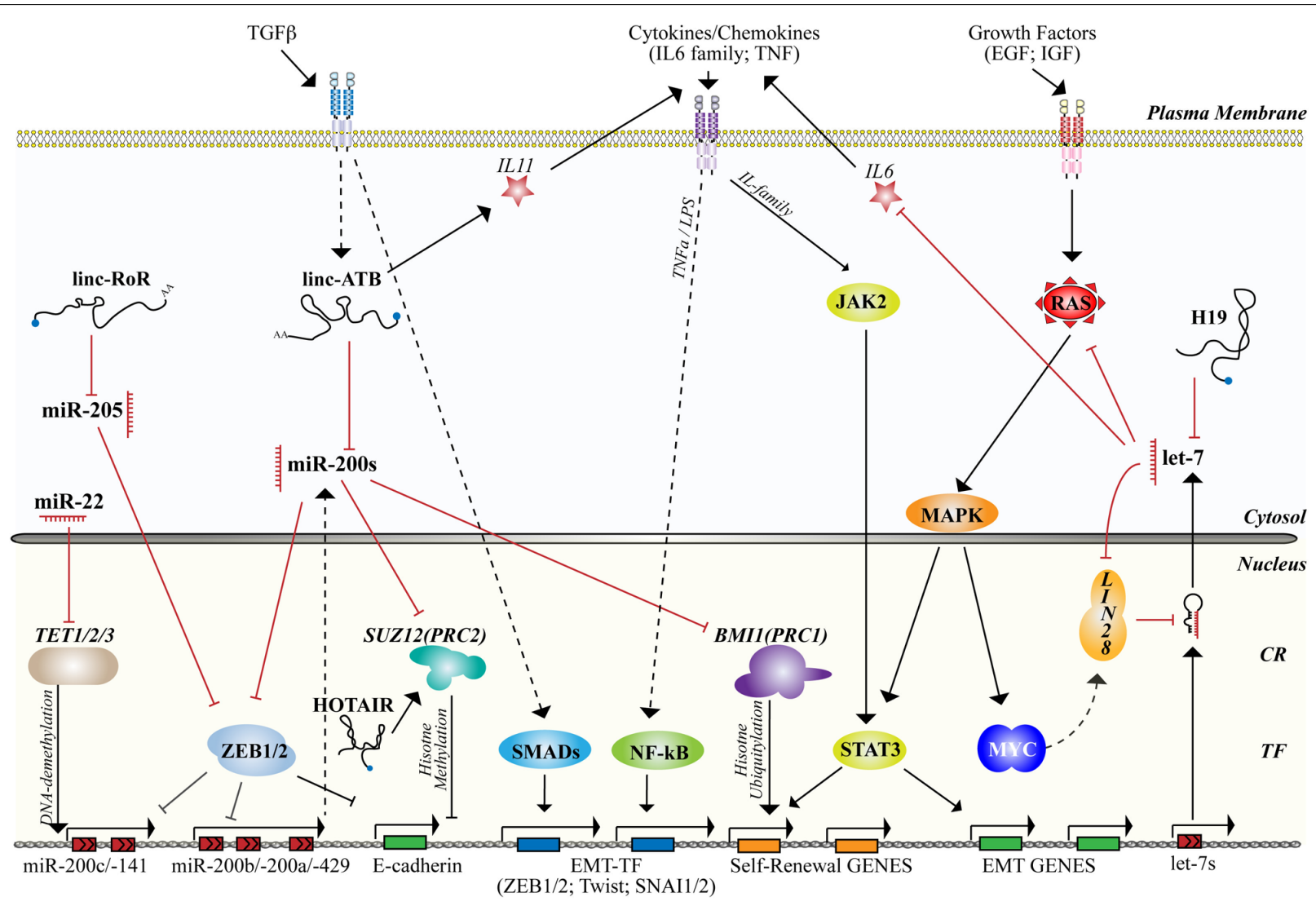

TF $=$ Transcriptional Factor CR= Chromatin Regulator

FIGURE 4 | microRNAs and IncRNAs control stemness and differentiation by interacting with signaling and transcriptional/ epigenetic networks. The figure summarizes the activity of the main miRNAs and IncRNAs involved in the control of normal or cancer mammary SCs together with signaling networks (cytosol) and the transcriptional/epigenetic framework (nucleus) to which they belong or that they regulate. Straight and dashed arrows refer to direct or indirect interaction/regulation, respectively. Red lines mark inhibitory interactions. The activity of transcriptional factors (TFs) and chromatin regulators (CRs), cited in the text and involved in the control of stemness and differentiation, are also shown. normal mouse mammary gland. Forced expression of one member of the family, miR-200c, repressed both normal mammary outgrowths in mammary gland reconstitution assays, and the in vivo tumorigenicity of human and mouse mammary CSCs. Mechanistically, this was linked to the ability of miR-200c to target BMI1 (B-lymphoma Mo-MLV insertion region 1 homolog), a component of the Polycomb Repressing Complex 1 (PRC1) and a critical regulator of SC self-renewal and differentiation (Shimono et al., 2009).

In a different setting, members of the miR-200 family were found to be downregulated in mammary CSCs (CD44 $4^{\text {high }} / \mathrm{CD} 24^{\text {low }}$ ) isolated from MCF10A cells transformed with the SRC oncogene (Iliopoulos et al., 2010). In this context, miR-200(s) targets SUZ12, a component of the PRC2, which epigenetically controls the expression of several genes, including E-cadherin, by H3K27 trimethylation. The miR-200/SUZ12/Ecadherin axis appeared to be important for the maintenance of mammary CSCs and in the regulation of metastasis. Overexpression of miR-200b or loss of SUZ12 expression inhibited mammosphere formation, invasion, and tumor growth from genetically distinct breast cancer cell lines, and cooperated with chemotherapy to prevent tumor relapse in xenograft models (Iliopoulos et al., 2010).

The notion of regulation of CSC traits by miR-200 has been further confirmed in multiple models (Brabletz et al., 2011; Chang et al., 2011; Chaffer et al., 2013; Lim etal., 2013; Song et al., 2013), and tightly linked to the function of EMT-TFs of the ZEB1/2 and to EMT (Christoffersen et al., 2007; Hurteau et al., 2007; Burk etal., 2008; Gregory et al., 2008; Korpal et al., 2008; Park et al., 2008; Scheel et al., 2011). Indeed, the expression of miR-200 family members is highly enriched in epithelial cells, almost absent in mesenchymal or basal cells, and positively correlates with the epithelial marker E-cadherin (Park et al., 2008). The E-box binding factors ZEB1 and ZEB2 possess a remarkable number of conserved binding sites for miR-200 miRNAs. A total of eight MREs are present in the $3^{\prime} \mathrm{UTR}$ of ZEB1 (5 for $\mathrm{miR}-200 \mathrm{bc} / 429$, and 3 for miR-200a and -141) and nine in ZEB2 (six for miR-200bc and three more for miR-200a/-141) (Christoffersen et al., 2007; Figure 4). Conversely, miR-200 genetic loci possess multiple binding site for $\mathrm{ZEB1/2}$, generating a double 
negative feedback loop that controls the epithelial or mesenchymal phenotype (Burk etal., 2008; Gregory etal., 2008; Korpal et al., 2008). This "switch" mechanism is one of the most representative examples of a transcriptional circuitry that regulates cell fate. The two players, ZEB1/2 and miR-200, which regulate the mesenchymal and the epithelial fate, respectively, are never in equilibrium: as one of the two starts accumulating the other disappears, critically contributing to the establishment of cell fate.

Studies from the Weinberg's lab, suggested a role for the ZEB1/miR-200 axis also in the regulation of cancer cell plasticity, by integrating external stimuli from the microenvironment (such as TGF- $\beta$ ) with epigenetic mechanisms (Chaffer et al., 2013). In several breast cancer cell lines, CD44 $4^{\text {low }}$ (non-CSC) and CD44 ${ }^{\text {high }}$ (CSCs) cells can interconvert into each other by regulating ZEB1 expression and, thus, miR-200 levels. Mechanistically, this occurs through the epigenetic regulation of the ZEB1 promoter, which converts from a poised state (with the coexistence of active and inactive chromatin marks - such as H3K4me3 and H3K27me3) to an active state (by removal of the repressing mark - H3K27me3) in response to TGF- $\beta$ signaling (Chaffer et al., 2013).

Finally, the ZEB1/miR-200 axis has been shown to interact with other pathways associated with SC-biology, such as the Notch pathway, by interfering with the ligand Jagged-1 (JAG1) and the mastermind-like co-activators MAML2 and MAML3 (Brabletz etal., 2011). Besides ZEB1 activity, at least two other mechanisms have been described that regulate miR-200 expression in mammary cells. The tumor suppressor p53 can regulate the expression of miR-200c, and the acquisition of EMT and SC properties, by directly binding and transactivating the miR-200c/141 locus in human normal mammary epithelial cells (Chang etal., 2011). Alternatively, the regulation of miR-200 clusters can be achieved epigenetically, by H3K27me3 histone modification at the miR-200b-a-429 locus (associated with gene silencing) induced upon autocrine TGF- $\beta$ signaling (Lim et al., 2013), or by $\mathrm{CpG}$ hypermethylation of promoter regions (Gregory et al., 2011).

\section{IncRNA-ATB AND EMT UPON TGF- $\beta$ STIMULATION}

The EMT program activated by TGF- $\beta$ stimulation also involves a lncRNA, named lncRNA-ATB (Activated by TGF- $\beta$ ). This cytoplasmic lncRNA has been identified among a group of 100 s of ncRNAs that are regulated upon TGF- $\beta$ stimulation in hepatocellular carcinomas, breast and colorectal cancer cell lines (Yuan et al., 2014). Bioinformatics predicted that lncRNA-ATB could act as a competing endogenous RNA for the miR-200 family, due to three putative binding regions for miR-200 (Yuan et al., 2014). Indeed, when expressed in cells, lncRNA-ATB phenocopies the pro-metastatic role of TGF- $\beta$ by inducing EMT and metastatic colonization. Mechanistically, this occurs through the positive modulation of the miR-200 targets, ZEB1 and ZEB2, via competition of lncRNA-ATB over miRNA-200(s). In hepatocellular carcinomas, high levels of IncRNA-ATB are predictive of poor survival and distant metastasis. Of note, while the EMT induction by lncRNA-ATB, and the early phase of tumor dissemination, could be fully rescued by miR-200 overexpression, the late metastatic colonization of lung and liver is miR-200-independent and mediated by the stabilization of IL-11 mRNA (directly bound by lncRNA-ATB), which in turn activates STAT3 signaling (Yuan et al., 2014). Hence, lncRNA-ATB drives EMT and metastasis by two independent mechanisms that impinge on different signaling modules that control CSC-traits (ZEB/miR-200s and IL-11/STAT3).

\section{miR-22 AND TET-FAMILY DEPENDENT CHROMATIN REMODELING}

miR-22 provides yet another regulatory module of miR-200 levels in mammary cells. This miRNA acts as an epigenetic regulator of EMT, stemness, and metastasis in estrogen receptor positive (ER+) breast cancers through the regulation of hypermethylation of the miR-200 promoter (Song et al., 2013). miR-22, which has been also found to be highly expressed in murine progenitor mammary cells (Ibarra et al., 2007), is upregulated in non-triple-negative breast cancers, positively correlating with high tumor grade and poor clinical outcome (Buffa et al., 2011; Enerly et al., 2011; Gregory et al., 2011; Song et al., 2013). When overexpressed in human or mouse mammary cells, miR-22 induces a transcriptional reprogramming, with upregulation of ZEB1/2 and downregulation of the miR-200 family, resulting in a mesenchymal phenotype, expansion of the MaSC pool, tumorigenesis and metastasis (Song et al., 2013). Mechanistically, these phenotypes are dependent on the methylation status of the miR-200 promoter and on the regulation of the TET (10 eleven translocation) family enzymes. These enzymes (TET1, TET2, and TET3) can modify DNA by removing the repressive 5 -methylcytosine mark $(5 \mathrm{mC})$ by hydroxylation and are all targeted by miR-22 (Tahiliani et al., 2009; Ito et al., 2010).

\section{THE miR-205/ZEB CIRCUIT AND linc-RoR}

miR-205 was identified as the most abundantly expressed miRNA in progenitor cells of the mammary gland, purified using ALDH as marker (Ibarra et al., 2007), suggesting a role for this miRNA in lineage specification and mammary gland formation. miR-205 is frequently downregulated in breast cancers and is associated with tumor relapse in patients with the triple negative subtype, which typically possess high CSC content (Sempere et al., 2007; Wang et al., 2013c). miR-205 is involved in the regulation of EMT through the targeting of ZEB1 (one conserved site) and ZEB2 (two conserved sites) and acts cooperatively with miRNAs of the miR-200 family in the specification of epithelial vs. mesenchymal fate (Gregory et al., 2008). A novel circuitry, which integrates signaling from the microenvironment with the induction of EMT has recently been described in breast cancer (Chao et al., 2014). In this case, the repression of miR-205 is achieved by the activation of Notch, mediated by the release of the ligand JAG1 by the tumor stroma, and the binding of the HES1 transcriptional repressor (an effector of the Notch pathway) directly to the miR-205 promoter. Loss of miR-205 increases ZEB1/2 levels and those of another target, NOTCH2, generating a feedback loop that controls epithelial polarization (by LLGL1 and LLGL2 genes), symmetric cell division, EMT, and mammary tumorigenesis (Chao et al., 2014).

This complex circuitry also involves the activity of at least another regulatory RNA, linc-RoR, a lncRNA involved in pluripotency and embryonic SCs (Loewer et al., 2010). Linc-RoR was 
found to be upregulated in breast tumor samples and was able to induce EMT in human immortalized mammary epithelial cells (MCF10A). The function of linc-RoR in the maintenance of induced pluripotent stem cells (iPSCs) and self-renewal of embryonic stem cells (ES cells) has been linked to its cytosolic localization and its ability to function as a competing endogenous RNA for tumor suppressive miRNAs (such as miR-145; Wang et al., 2013b). Similarly, in the breast compartment, linc-RoR interacts with endogenous miR-205 and induces the derepression of ZEB2, fostering the EMT program and the acquisition of SC traits by cancer cells (Hou et al., 2014).

\section{HOTAIR AND PRC2}

HOX antisense intergenic RNA is a lncRNA generated by antisense transcription of the HOXC gene cluster (Rinn et al., 2007). The primary function of HOTAIR is during embryonic development, when it regulates the silencing of the distant HOXD locus (transregulation), acting as a scaffold and bringing two different chromatin remodeling complexes to the same locus to enforce gene silencing (Rinn et al., 2007). This recruitment of chromatin remodelers is mediated by two different RNA domains in HOTAIR: (i) one comprising the first 300 nts of HOTAIR, which physically associate with the PRC2 complex via EZH2 to induce $\mathrm{H} 3 \mathrm{~K} 27 \mathrm{me} 3$; and (ii) the other comprising the last $700 \mathrm{nts}$ of HOTAIR, which bind to the LSD1-coREST complex that demethylates $\mathrm{H} 3 \mathrm{~K} 4 \mathrm{me} 2$, hence reinforcing transcriptional repression (Tsai et al., 2010).

HOX antisense intergenic RNA is also frequently upregulated in breast cancer metastasis, and its expression in primary tumors is a predictor of invasiveness and adverse outcome, particularly in ER-positive cancers (Gupta et al., 2010; Gutschner and Diederichs, 2012). The overexpression of HOTAIR is sufficient to promote invasion and metastasis of breast cancer cells by re-directing the activity of the PRC2 complex to hundreds of genes, including many metastasis suppressor genes (Gupta et al., 2010). Accordingly, HOTAIR silencing inhibits metastasis, especially in cells with high PRC2 activity (Gupta et al., 2010). Intriguingly, the Breast Cancer 1, early onset gene (BRCA1), whose mutations are responsible for a number of inherited breast cancers, inhibits the interaction between PRC2 and HOTAIR by competing with HOTAIR for binding to EZH2. This observation suggests that BRCA1 loss could induce tumorigenesis also by an EZH2/HOTAIR-dependent mechanism (Wang et al., 2013a).

Elevated levels of HOTAIR are predictive of unfavorable prognosis in other cancers (such as colon and liver) pointing to a more general role in oncogenesis (Kogo et al., 2011; Yang et al., 2011). Indeed, EMT induced by TGF- $\beta$ treatment in colon (DLD-1/HT29) and mammary (MCF10A) cell lines was shown to involve and be dependent on HOTAIR expression (Pádua Alves et al., 2013).

Finally, since HOTAIR regulates the HOXD locus, it has been suggested that this lncRNA downregulates another miRNA associated with EMT, miR-7, which is dependent on HoxD10 (Reddy et al., 2008). Indeed, miR-7 modulates the histone methyl transferase SETDB1, regulating a STAT3-dependent EMT, and acquisition of SC traits in CD $44^{+}$cells derived from MDA-MB-231 human breast cancer cells (Zhang et al., 2014).

\section{CONCLUDING REMARKS}

By sitting at the intersection of complex circuitries that integrate transcriptional, post-transcriptional, and epigenetic control, ncRNAs exert a pervasive function on cell regulation. We are only starting to appreciate the relevance of this new layer of organization in the cellular 'master plan,' and the impact of its subversion in diseases. Indeed, deciphering the role of ncRNAs in cancer is especially desirable, not only from the perspective of understanding the molecular basis of this disease, but also with the view of developing novel clinical tools and treatments. With this outlook in mind, a number of important cultural and technological challenges lay ahead of us.

First, a true understanding of the functions of ncRNAs can be obtained only at the systems level. This seems to be necessitated by the very nature of the workings of this class of regulators, which act on multiple targets and are integrated in multiple cellular molecular functions, thus, affecting phenotypes in complex ways. Simply put, the reductionistic approach (even when sophisticated) that has served us reasonably well in deciphering gene function is bound to produce limited knowledge on the biology of ncRNAs. We will have to devise strategies that contemplate the integration of multiple omics approaches, including transcriptomics, proteomics, and epigenomics, in addition to phenotypical analysis, to understand the impact of the experimental modulation of the levels of ncRNAs. And yet, high throughput analysis will not suffice. High-resolution studies will also be needed, including quantitative assessment, analysis of threshold levels of action, resolution of the signals in space and time, dependency on cellular context and developmental stage.

In the particular case of lncRNAs, a series of additional limitations will have to be overcome. A major challenge will be to obtain the complete annotation of tissue-specific and/or cell type-specific lncRNAs, a task that might require years. More importantly, we will need to define genetic models to study their functions. This represents a formidable task: the genomic loci of lncRNAs are frequently located in gene-rich areas, often overlapping with other genetic units, which renders traditional knock-out or knock-in strategies less than ideal. Moreover, the fact that lncRNAs frequently exert positional effects in cis further complicates their analysis.

However, the field of applications for ncRNAs, especially in cancer, harbors great promise. The expression of ncRNAs, especially lncRNAs, is tightly and specifically regulated in time and as a function of the cellular context. This property makes them appealing diagnostic markers, since they can distinguish between cell types in the same tissue and between different functional states of the same lineage (for instance, cells poised for EMT). Their application as markers, for diagnostic/prognostic assessment and for therapy stratification seems, therefore, a reasonable perspective.

The ultimate goal, obviously, would be to exploit ncRNAs as therapeutic tools. The evidence, herein reviewed, that these molecules have a key role in cell fate determination and in the modulation of cellular plasticity, leading to the acquisition of stem-related properties, support such a possibility. One important advantage of ncRNA-based therapies would be the wide range of intracellular targets, which should minimize the possibility of 
escape (drug resistance) due to the acquisition of secondary mutations by cancer cells. One of the major hurdles, on the other hand, resides in the lack of suitable (and specific) vectors for delivery, a problem shared with all forms of gene therapy in cancer. However, ncRNAs might possess an intrinsic and exploitable advantage. Given their multi-target characteristics, the action of ncRNAs might be, at least in some cases, cell-context dependent. In other words, the modulation of ncRNA levels might not lead to stereotypical consequences in all cell types, but to (more or less) specific ones, as a function of the cell type. If so, the need for specific delivery might be alleviated, at least in part, if the "right" ncRNA can be selected to exert the desired effect only in the desired cell types. Clearly, a deeper understanding of the biological effects of the various ncRNAs will need to be acquired before this possibility can be actualized into real therapeutic strategies.

\section{ACKNOWLEDGMENTS}

We thank Salvatore Pece, Paola Bonetti, and Matteo Marzi for critical suggestions. Work in the authors' labs is supported by grants from the Associazione Italiana per la Ricerca sul Cancro (AIRC \#14085 to FN, and \#10349, 14404 and MCO 10.000 to PDF); from the European Research Council (MAMMASTEM) to PDF; from the Italian Ministry of Health to PDF; from the Monzino Foundation to PDF.

\section{REFERENCES}

Aceto, N., Sausgruber, N., Brinkhaus, H., Gaidatzis, D., Martiny-Baron, G., Mazzarol, G., et al. (2012). Tyrosine phosphatase SHP2 promotes breast cancer progression and maintains tumor-initiating cells via activation of key transcription factors and a positive feedback signaling loop. Nat. Med. 18, 529-537. doi: $10.1038 / \mathrm{nm} .2645$

Al-Hajj, M. (2003). From the cover: prospective identification of tumorigenic breast cancer cells. Proc. Natl. Acad. Sci. U.S.A. 100, 3983-3988. doi: 10.1073/pnas.0530291100

Ambros, V. (2004). The functions of animal microRNAs. Nature 431, 350-355. doi: 10.1038 /nature02871

Auyeung, V. C., Ulitsky, I., Mcgeary, S. E., and Bartel, D. P. (2013). Beyond secondary structure: primary-sequence determinants license pri-miRNA hairpins for processing. Cell 152, 844-858. doi: 10.1016/j.cell.2013.01.031

Baccarini, A., Chauhan, H., Gardner, T. J., Jayaprakash, A. D., Sachidanandam, R., and Brown, B. D. (2011). Kinetic analysis reveals the fate of a microRNA following target regulation in mammalian cells. Curr. Biol. 21, 369-376. doi: 10.1016/j.cub.2011.01.067

Barsyte-Lovejoy, D., Lau, S. K., Boutros, P. C., Khosravi, F., Jurisica, I., Andrulis, I. L., et al. (2006). The c-Myc oncogene directly induces the H19 noncoding RNA by allele-specific binding to potentiate tumorigenesis. Cancer Res. 66, 5330-5337. doi: 10.1158/0008-5472.CAN-06-0037

Bartel, D. P. (2009). MicroRNAs: target recognition and regulatory functions. Cell 136, 215-233. doi: 10.1016/j.cell.2009.01.002

Bartolomei, M. S., Zemel, S., and Tilghman, S. M. (1991). Parental imprinting of the mouse H19 gene. Nature 351, 153-155. doi: 10.1038/351153a0

Bazzini, A. A., Johnstone, T. G., Christiano, R., Mackowiak, S. D., Obermayer, B., Fleming, E. S., et al. (2014). Identification of small ORFs in vertebrates using ribosome footprinting and evolutionary conservation. EMBO J. 33, 981-993. doi: 10.1002/embj.201488411

Berezikov, E. (2011). Evolution of microRNA diversity and regulation in animals. Nat. Rev. Genet. 12, 846-860. doi: 10.1038/nrg3079

Berezikov, E., Chung, W. J., Willis, J., Cuppen, E., and Lai, E. C. (2007). Mammalian mirtron genes. Mol. Cell. 28, 328-336. doi: 10.1016/j.molcel.2007.09.028

Bernstein, E., Caudy, A. A., Hammond, S. M., and Hannon, G. J. (2001). Role for a bidentate ribonuclease in the initiation step of RNA interference. Nature 409, 363-366. doi: 10.1038/35053110

Berteaux, N., Lottin, S., Monte, D., Pinte, S., Quatannens, B., Coll, J., et al. (2005). H19 mRNA-like noncoding RNA promotes breast cancer cell proliferation through positive control by E2F1. J. Biol. Chem. 280, 29625-29636. doi: 10.1074/jbc.M504033200

Bhat-Nakshatri, P., Wang, G., Collins, N. R., Thomson, M. J., Geistlinger, T. R., Carroll, J. S., et al. (2009). Estradiol-regulated microRNAs control estradiol response in breast cancer cells. Nucleic Acids Res. 37, 4850-4861. doi: 10.1093/nar/ gkp500

Brabletz, S., Bajdak, K., Meidhof, S., Burk, U., Niedermann, G., Firat, E., et al. (2011). The ZEB1/miR-200 feedback loop controls Notch signalling in cancer cells. EMBO J. 30, 770-782. doi: 10.1038/emboj.2010.349

Brannan, C. I., Dees, E. C., Ingram, R. S., and Tilghman, S. M. (1990). The product of the $\mathrm{H} 19$ gene may function as an RNA. Mol. Cell. Biol. 10, 28-36.

Buffa, F. M., Camps, C., Winchester, L., Snell, C. E., Gee, H. E., Sheldon, H., et al. (2011). microRNA-associated progression pathways and potential therapeutic targets identified by integrated $\mathrm{mRNA}$ and microRNA expression profiling in breast cancer. Cancer Res. 71, 5635-5645. doi: 10.1158/0008-5472.CAN-1 1-0489

Burk, U., Schubert, J., Wellner, U., Schmalhofer, O., Vincan, E., Spaderna, S., et al. (2008). A reciprocal repression between ZEB1 and members of the miR-200 family promotes EMT and invasion in cancer cells. EMBO Rep. 9, 582-589. doi: 10.1038/embor.2008.74

Bushati, N., and Cohen, S. M. (2007). microRNA functions. Annu. Rev. Cell Dev. Biol. 23, 175-205. doi: 10.1146/annurev.cellbio.23.090506.123406

Cabili, M. N., Trapnell, C., Goff, L., Koziol, M., Tazon-Vega, B., Regev, A., et al. (2011). Integrative annotation of human large intergenic noncoding RNAs reveals global properties and specific subclasses. Genes Dev. 25, 1915-1927. doi: 10.1101/gad.17446611

Cai, W. Y., Wei, T. Z., Luo, Q. C., Wu, Q. W., Liu, Q. F., Yang, M., et al. (2013). The Wnt-beta-catenin pathway represses let-7 microRNA expression through transactivation of Lin 28 to augment breast cancer stem cell expansion. J. Cell Sci. 126, 2877-2889. doi: 10.1242/jcs. 123810

Cai, X., and Cullen, B. R. (2007). The imprinted H19 noncoding RNA is a primary microRNA precursor. RNA 13, 313-316. doi: 10.1261/rna.351707

Carthew, R. W., and Sontheimer, E. J. (2009). Origins and mechanisms of miRNAs and siRNAs. Cell 136, 642-655. doi: 10.1016/j.cell.2009.01.035

Cech, T. R., and Steitz, J. A. (2014). The noncoding RNA revolution-trashing old rules to forge new ones. Cell 157, 77-94. doi: 10.1016/j.cell.2014.03.008

Chaffer, C. L., Brueckmann, I., Scheel, C., Kaestli, A. J., Wiggins, P. A., Rodrigues, L. O., et al. (2011). Normal and neoplastic nonstem cells can spontaneously convert to a stem-like state. Proc. Natl. Acad. Sci. U.S.A. 108, 7950-7955. doi: 10.1073/pnas. 1102454108

Chaffer, C. L., Marjanovic, N. D., Lee, T., Bell, G., Kleer, C. G., Reinhardt, F., etal. (2013). Poised chromatin at the ZEB1 promoter enables breast cancer cell plasticity and enhances tumorigenicity. Cell 154, 61-74. doi: 10.1016/j.cell.2013.06.005

Chang, C. J., Chao, C. H., Xia, W., Yang, J. Y., Xiong, Y., Li, C. W., et al. (2011). p53 regulates epithelial-mesenchymal transition and stem cell properties through modulating miRNAs. Nat. Cell Biol. 13, 317-323. doi: 10.1038/ ncb 2173

Chao, C. H., Chang, C. C., Wu, M. J., Ko, H. W., Wang, D., Hung, M. C., et al. (2014). MicroRNA-205 signaling regulates mammary stem cell fate and tumorigenesis J. Clin. Invest. 124, 3093-3106. doi: 10.1172/JCI73351

Chatterjee, S., and Grosshans, H. (2009). Active turnover modulates mature microRNA activity in Caenorhabditis elegans. Nature 461, 546-549. doi: 10.1038/nature08349

Christoffersen, N. R., Silahtaroglu, A., Orom, U. A., Kauppinen, S., and Lund, A. H. (2007). miR-200b mediates post-transcriptional repression of ZFHX1B. RNA 13, 1172-1178. doi: 10.1261/rna.586807

Cicalese, A., Bonizzi, G., Pasi, C. E., Faretta, M., Ronzoni, S., Giulini, B., et al. (2009). The tumor suppressor p53 regulates polarity of self-renewing divisions in mammary stem cells. Cell 138, 1083-1095. doi: 10.1016/j.cell.2009. 06.048

Creighton, C. J., Li, X., Landis, M., Dixon, J. M., Neumeister, V. M., Sjolund, A., et al. (2009). Residual breast cancers after conventional therapy display mesenchymal as well as tumor-initiating features. Proc. Natl. Acad. Sci. U.S.A. 106, 13820-13825. doi: 10.1073/pnas.0905718106

De, N., Young, L., Lau, P. W., Meisner, N. C., Morrissey, D. V., and Macrae, I. J. (2013). Highly complementary target RNAs promote release of guide RNAs from human Argonaute2. Mol. Cell 50, 344-355. doi: 10.1016/j.molcel.2013. 04.001 
Denli, A. M., Tops, B. B., Plasterk, R. H., Ketting, R. F., and Hannon, G. J. (2004). Processing of primary microRNAs by the Microprocessor complex. Nature 432, 231-235. doi: 10.1038/nature03049

Deome, K. B., Faulkin, L. J. Jr., Bern, H. A., and Blair, P. B. (1959). Development of mammary tumors from hyperplastic alveolar nodules transplanted into glandfree mammary fat pads of female C3H mice. Cancer Res. 19, 515-520.

Derrien, T., Johnson, R., Bussotti, G., Tanzer, A., Djebali, S., Tilgner, H., et al. (2012). The GENCODE v7 catalog of human long noncoding RNAs: analysis of their gene structure, evolution, and expression. Genome Res. 22, 1775-1789. doi: 10.1101/gr.132159.111

DeSantis, C., Ma, J., Bryan, L., and Jemal, A. (2014). Breast cancer statistics, 2013. CA Cancer J. Clin. 64, 52-62. doi: 10.3322/caac.21203

Djebali, S., Davis, C. A., Merkel, A., Dobin, A., Lassmann, T., Mortazavi, A., et al. (2012). Landscape of transcription in human cells. Nature 489, 101-108. doi: 10.1038 /nature 11233

Dontu, G., Abdallah, W. M., Foley, J. M., Jackson, K. W., Clarke, M. F., Kawamura, M. J., et al. (2003). In vitro propagation and transcriptional profiling of human mammary stem/progenitor cells. Genes Dev. 17, 1253-1270. doi: $10.1101 /$ gad.1061803

Dugimont, T., Montpellier, C., Adriaenssens, E., Lottin, S., Dumont, L., Iotsova, V., et al. (1998). The H19 TATA-less promoter is efficiently repressed by wild-type tumor suppressor gene product p53. Oncogene 16, 2395-2401. doi: 10.1038/sj.onc. 1201742

Ebisuya, M., Yamamoto, T., Nakajima, M., and Nishida, E. (2008). Ripples from neighbouring transcription. Nat. Cell Biol. 10, 1106-1113. doi: 10.1038/ncb1771

Enerly, E., Steinfeld, I., Kleivi, K., Leivonen, S. K., Aure, M. R., Russnes, H. G., et al. (2011). miRNA-mRNA integrated analysis reveals roles for miRNAs in primary breast tumors. PLoS ONE 6:e16915. doi: 10.1371/journal.pone.0016915

Gabory, A., Jammes, H., and Dandolo, L. (2010). The H19 locus: role of an imprinted non-coding RNA in growth and development. Bioessays 32, 473-480. doi: 10.1002/bies.200900170

Gangaraju, V. K., and Lin, H. (2009). MicroRNAs: key regulators of stem cells. Nature reviews. Mol. Cell Biol. 10, 116-125. doi: 10.1038/nrm2621

Garzon, R., Calin, G. A., and Croce, C. M. (2009). MicroRNAs in Cancer. Annu. Rev. Med. 60, 167-179. doi: 10.1146/annurev.med.59.053006.104707

Gregory, P. A., Bert, A. G., Paterson, E. L., Barry, S. C., Tsykin, A., Farshid, G., et al. (2008). The miR-200 family and miR-205 regulate epithelial to mesenchymal transition by targeting ZEB1 and SIP1. Nat. Cell Biol. 10, 593-601. doi: $10.1038 /$ ncb 1722

Gregory, P. A., Bracken, C. P., Smith, E., Bert, A. G., Wright, J. A., Roslan, S., et al. (2011). An autocrine TGF-beta/ZEB/miR-200 signaling network regulates establishment and maintenance of epithelial-mesenchymal transition. Mol. Biol. Cell 22, 1686-1698. doi: 10.1091/mbc.E11-02-0103

Gregory, R. I., Yan, K. P., Amuthan, G., Chendrimada, T., Doratotaj, B., Cooch, N., et al. (2004). The Microprocessor complex mediates the genesis of microRNAs. Nature 432, 235-240. doi: 10.1038/nature03120

Guo, L., Chen, C., Shi, M., Wang, F., Chen, X., Diao, D., et al. (2013). Stat3-coordinated Lin-28-let-7-HMGA2 and miR-200-ZEB1 circuits initiate and maintain oncostatin M-driven epithelial-mesenchymal transition. Oncogene 32, 5272-5282. doi: 10.1038/onc.2012.573

Guo, W., Keckesova, Z., Donaher, J. L., Shibue, T., Tischler, V., Reinhardt, F., et al. (2012). Slug and Sox9 cooperatively determine the mammary stem cell state. Cell 148, 1015-1028. doi: 10.1016/j.cell.2012.02.008

Gupta, P. B., Fillmore, C. M., Jiang, G., Shapira, S. D., Tao, K., Kuperwasser, C., et al. (2011). Stochastic state transitions give rise to phenotypic equilibrium in populations of cancer cells. Cell 146, 633-644. doi: 10.1016/j.cell.2011.07.026

Gupta, R. A., Shah, N., Wang, K. C., Kim, J., Horlings, H. M., Wong, D. J., et al. (2010). Long non-coding RNA HOTAIR reprograms chromatin state to promote cancer metastasis. Nature 464, 1071-1076. doi: 10.1038/nature08975

Gutschner, T., and Diederichs, S. (2012). The hallmarks of cancer: a long non-coding RNA point of view. RNA Biol. 9, 703-719. doi: 10.4161/rna.20481

Guttman, M., Amit, I., Garber, M., French, C., Lin, M. F., Feldser, D., et al. (2009). Chromatin signature reveals over a thousand highly conserved large non-coding RNAs in mammals. Nature 458, 223-227. doi: 10.1038/nature07672

Guttman, M., and Rinn, J. L. (2012). Modular regulatory principles of large noncoding RNAs. Nature 482, 339-346. doi: 10.1038/nature10887

Ha, M., and Kim, V. N. (2014). Regulation of microRNA biogenesis. Nat. Rev. Mol. Cell Biol. 15, 509-524. doi: 10.1038/nrm3838
Hammond, S. M., Boettcher, S., Caudy, A. A., Kobayashi, R., and Hannon, G. J. (2001). Argonaute2, a link between genetic and biochemical analyses of RNAi. Science 293, 1146-1150. doi: 10.1126/science.1064023

Han, J., Lee, Y., Yeom, K. H., Nam, J. W., Heo, I., Rhee, J. K., et al. (2006). Molecular basis for the recognition of primary microRNAs by the Drosha-DGCR8 complex. Cell 125, 887-901. doi: 10.1016/j.cell.2006.03.043

Hanahan, D., and Weinberg, R. A. (2011). Hallmarks of cancer: the next generation. Cell 144, 646-674. doi: 10.1016/j.cell.2011.02.013

Hausser, J., and Zavolan, M. (2014). Identification and consequences of miRNAtarget interactions-beyond repression of gene expression. Nat. Rev. Genet. 15, 599-612. doi: 10.1038/nrg3765

Hou, P., Zhao, Y., Li, Z., Yao, R., Ma, M., Gao, Y., et al. (2014). LincRNA-ROR induces epithelial-to-mesenchymal transition and contributes to breast cancer tumorigenesis and metastasis. Cell Death Dis. 5, e1287. doi: 10.1038/cddis.2014.249

Hurteau, G. J., Carlson, J. A., Spivack, S. D., and Brock, G. J. (2007). Overexpression of the microRNA hsa-miR-200c leads to reduced expression of transcription factor 8 and increased expression of E-cadherin. Cancer Res. 67, 7972-7976. doi: 10.1158/0008-5472.CAN-07-1058

Ibarra, I., Erlich, Y., Muthuswamy, S. K., Sachidanandam, R., and Hannon, G. J. (2007). A role for microRNAs in maintenance of mouse mammary epithelial progenitor cells. Genes Dev. 21, 3238-3243. doi: 10.1101/gad.1616307

Iliopoulos, D., Hirsch, H. A., and Struhl, K. (2009). An epigenetic switch involving NF-kappaB, Lin28, Let-7 MicroRNA, and IL6 links inflammation to cell transformation. Cell 139, 693-706. doi: 10.1016/j.cell.2009.10.014

Iliopoulos, D., Lindahl-Allen, M., Polytarchou, C., Hirsch, H. A., Tsichlis, P. N., and Struhl, K. (2010). Loss of miR-200 inhibition of Suz12 leads to polycombmediated repression required for the formation and maintenance of cancer stem cells. Mol. Cell 39, 761-772. doi: 10.1016/j.molcel.2010.08.013

Ingolia, N. T., Lareau, L. F., and Weissman, J. S. (2011). Ribosome profiling of mouse embryonic stem cells reveals the complexity and dynamics of mammalian proteomes. Cell 147, 789-802. doi: 10.1016/j.cell.2011.10.002

Ito, S., D’Alessio, A. C., Taranova, O. V., Hong, K., Sowers, L. C., and Zhang, Y. (2010). Role of Tet proteins in $5 \mathrm{mC}$ to $5 \mathrm{hmC}$ conversion, ES-cell self-renewal and inner cell mass specification. Nature 466, 1129-1133. doi: 10.1038/nature 09303

Kallen, A. N., Zhou, X.-B., Xu, J., Qiao, C., Ma, J., Yan, L., et al. (2013). The imprinted H19 lncRNA antagonizes let-7 microRNAs. Mol. Cell 52, 101-112. doi: 10.1016/j.molcel.2013.08.027

Kapranov, P., Cheng, J., Dike, S., Nix, D. A., Duttagupta, R., Willingham, A. T., et al. (2007). RNA maps reveal new RNA classes and a possible function for pervasive transcription. Science 316, 1484-1488. doi: 10.1126/science.1138341

Khvorova, A., Reynolds, A., and Jayasena, S. D. (2003). Functional siRNAs and miRNAs exhibit strand bias. Cell 115, 209-216. doi: 10.1016/S0092-8674(03)00801-8

Kogo, R., Shimamura, T., Mimori, K., Kawahara, K., Imoto, S., Sudo, T., et al. (2011). Long noncoding RNA HOTAIR regulates polycomb-dependent chromatin modification and is associated with poor prognosis in colorectal cancers. Cancer Res. 71, 6320-6326. doi: 10.1158/0008-5472.CAN-11-1021

Kordon, E. C., and Smith, G. H. (1998). An entire functional mammary gland may comprise the progeny from a single cell. Development 125, 1921-1930.

Korpal, M., Lee, E. S., Hu, G., and Kang, Y. (2008). The miR-200 family inhibits epithelial-mesenchymal transition and cancer cell migration by direct targeting of E-cadherin transcriptional repressors ZEB1 and ZEB2. J. Biol. Chem. 283, 14910-14914. doi: 10.1074/jbc.C800074200

Kozomara, A., and Griffiths-Jones, S. (2014). miRBase: annotating high confidence microRNAs using deep sequencing data. Nucleic Acids Res. 42, D68-D73. doi: 10.1093/nar/gkt1181

Krol, J., Loedige, I., and Filipowicz, W. (2010). The widespread regulation of microRNA biogenesis, function and decay. Nat. Rev. Genet. 11, 597-610. doi: $10.1038 / \mathrm{nrg} 2843$

Lagos-Quintana, M., Rauhut, R., Lendeckel, W., and Tuschl, T. (2001). Identification of novel genes coding for small expressed RNAs. Science 294, 853-858. doi: 10.1126/science.1064921

Lee, R. C., Feinbaum, R. L., and Ambros, V. (1993). The C. elegans heterochronic gene lin-4 encodes small RNAs with antisense complementarity to lin-14. Cell 75, 843-854. doi: 10.1016/0092-8674(93)90529-Y

Lee, Y., Jeon, K., Lee, J. T., Kim, S., and Narry Kim, V. (2002). MicroRNA maturation: stepwise processing and subcellular localization. EMBO J. 21, 4663-4670. doi: $10.1093 / \mathrm{emboj} / \mathrm{cdf} 476$ 
Lehmann, B. D., Bauer, J. A., Chen, X., Sanders, M. E., Chakravarthy, A. B., Shyr, Y., et al. (2011). Identification of human triple-negative breast cancer subtypes and preclinical models for selection of targeted therapies. J. Clin. Invest. 121, 2750-2767. doi: 10.1172/JCI45014

Li, X., Lewis, M. T., Huang, J., Gutierrez, C., Osborne, C. K., Wu, M. F., et al. (2008). Intrinsic resistance of tumorigenic breast cancer cells to chemotherapy. J. Natl. Can. Inst. 100, 672-679. doi: 10.1093/jnci/djn123

Lim, Y.-Y., Wright, J. A., Attema, J. L., Gregory, P. A., Bert, A. G., Smith, E., et al. (2013). Epigenetic modulation of the miR-200 family is associated with transition to a breast cancer stem-cell-like state. J. Cell Sci. 126, 2256-2266. doi: $10.1242 /$ jcs. 122275

Lin, M. F., Jungreis, I., and Kellis, M. (2011). PhyloCSF: a comparative genomics method to distinguish protein coding and non-coding regions. Bioinformatics 27, i275-i282. doi: 10.1093/bioinformatics/btr209

Liu, S., and Wicha, M. S. (2010). Targeting breast cancer stem cells. J. Clin. Oncol. 28, 4006-4012. doi: 10.1200/JCO.2009.27.5388

Loewer, S., Cabili, M. N., Guttman, M., Loh, Y. H., Thomas, K., Park, I. H., et al. (2010). Large intergenic non-coding RNA-RoR modulates reprogramming of human induced pluripotent stem cells. Nat. Genet. 42, 1113-1117. doi: 10.1038/ng.710

Lujambio, A., and Lowe, S. W. (2012). The microcosmos of cancer. Nature 482, 347-355. doi: 10.1038/nature10888

Lund, E., Guttinger, S., Calado, A., Dahlberg, J. E., and Kutay, U. (2004). Nuclear export of microRNA precursors. Science 303, 95-98. doi: 10.1126/science.1090599

Mani, S. A., Guo, W., Liao, M.-J., Eaton, E. N., Ayyanan, A., Zhou, A. Y., et al. (2008). The epithelial-mesenchymal transition generates cells with properties of stem cells. Cell 133, 704-715. doi: 10.1016/j.cell.2008.03.027

Marotta, L. L. C., Almendro, V., Marusyk, A., Shipitsin, M., Schemme, J., Walker, S. R., et al. (2011). The JAK2/STAT3 signaling pathway is required for growth of $\mathrm{CD} 44^{+} \mathrm{CD} 24^{-}$stem cell-like breast cancer cells in human tumors. J. Clin. Invest. 121, 2723-2735. doi: 10.1172/JCI44745

Matouk, I. J., Degroot, N., Mezan, S., Ayesh, S., Abu-Lail, R., Hochberg, A., et al. (2007). The H19 non-coding RNA is essential for human tumor growth. PLoS ONE 2:e845. doi: 10.1371/journal.pone.0000845

Matouk, I. J., Raveh, E., Abu-Lail, R., Mezan, S., Gilon, M., Gershtain, E., et al. (2014). Oncofetal H19 RNA promotes tumor metastasis. Biochim. Biophys. Acto 1843, 1414-1426. doi: 10.1016/j.bbamcr.2014.03.023

Medema, J. P. (2013). Cancer stem cells: the challenges ahead. Nat. Cell Biol. 15, 338-344. doi: $10.1038 /$ ncb2717

Mercer, T., Dinger, M. E., and Mattick, J. S. (2009). Long non-coding RNAs: insights into functions. Nat. Rev. Genet. 10, 155-159. doi: 10.1038/nrg2521

Mikkelsen, T. S., Ku, M., Jaffe, D. B., Issac, B., Lieberman, E., Giannoukos, G., et al. (2007). Genome-wide maps of chromatin state in pluripotent and lineage-committed cells. Nature 448, 553-560. doi: 10.1038/nature 06008

Mori, M., Triboulet, R., Mohseni, M., Schlegelmilch, K., Shrestha, K., Camargo, F. D., et al. (2014). Hippo signaling regulates microprocessor and links celldensity-dependent miRNA biogenesis to cancer. Cell 156, 893-906. doi: 10.1016/j.cell.2013.12.043

Mourelatos, Z., Dostie, J., Paushkin, S., Sharma, A., Charroux, B., Abel, L., et al. (2002). miRNPs: a novel class of ribonucleoproteins containing numerous microRNAs. Genes Dev. 16, 720-728. doi: 10.1101/gad.974702

Pádua Alves, C., Fonseca, A. S., Muys, B. R., De Barros, E., Lima Bueno, R., Bürger, M. C., et al. (2013). Brief report: the lincRNA hotair is required for epithelial-tomesenchymal transition and stemness maintenance of cancer cell lines. Stem cells 31, 2827-2832. doi: 10.1002/stem.1547

Park, S. M., Gaur, A. B., Lengyel, E., and Peter, M. E. (2008). The miR-200 family determines the epithelial phenotype of cancer cells by targeting the Ecadherin repressors ZEB1 and ZEB2. Genes Dev. 22, 894-907. doi: 10.1101/gad.16 40608

Pece, S., Tosoni, D., Confalonieri, S., Mazzarol, G., Vecchi, M., Ronzoni, S., et al. (2010). Biological and molecular heterogeneity of breast cancers correlates with their cancer stem cell content. Cell 140, 62-73. doi: 10.1016/j.cell.2009. 12.007

Perou, C. M., Sorlie, T., Eisen, M. B., Van De Rijn, M., Jeffrey, S. S., Rees, C. A., et al. (2000). Molecular portraits of human breast tumours. Nature 406, 747-752. doi: $10.1038 / 35021093$
Piskounova, E., Polytarchou, C., Thornton, J. E., Lapierre, R. J., Pothoulakis, C., Hagan, J. P., etal. (2011). Lin28A and Lin28B inhibit let-7 microRNA biogenesis by distinct mechanisms. Cell 147, 1066-1079. doi: 10.1016/j.cell.2011. 10.039

Ponting, C. P., Oliver, P. L., and Reik, W. (2009). Evolution and functions of long noncoding RNAs. Cell 136, 629-641. doi: 10.1016/j.cell.2009.02.006

Prat, A., and Perou, C. M. (2011). Deconstructing the molecular portraits of breast cancer. Mol. Oncol. 5, 5-23. doi: 10.1016/j.molonc.2010.11.003

Ravasi, T., Suzuki, H., Pang, K. C., Katayama, S., Furuno, M., Okunishi, R., et al. (2006). Experimental validation of the regulated expression of large numbers of non-coding RNAs from the mouse genome. Genome Res. 16, 11-19. doi: 10.1101/gr.4200206

Reddy, S. D., Ohshiro, K., Rayala, S. K., and Kumar, R. (2008). MicroRNA7, a homeobox D10 target, inhibits p21-activated kinase 1 and regulates its functions. Cancer Res. 68, 8195-8200. doi: 10.1158/0008-5472.CAN08-2103

Reinhart, B. J., Slack, F. J., Basson, M., Pasquinelli, A. E., Bettinger, J. C., Rougvie, A. E., et al. (2000). The 21-nucleotide let-7 RNA regulates developmental timing in Caenorhabditis elegans. Nature 403, 901-906. doi: 10.1038/35002607

Rinn, J. L., and Chang, H. Y. (2012). Genome regulation by long noncoding RNAs. Annu. Rev. Biochem. 81, 145-166. doi: 10.1146/annurev-biochem-051410092902

Rinn, J. L., Kertesz, M., Wang, J. K., Squazzo, S. L., Xu, X., Brugmann, S. A., et al. (2007). Functional demarcation of active and silent chromatin domains in human HOX loci by noncoding RNAs. Cell 129, 1311-1323. doi: 10.1016/j.cell.2007.05.022

Rios, A. C., Fu, N. Y., Lindeman, G. J., and Visvader, J. E. (2014). In situ identification of bipotent stem cells in the mammary gland. Nature 506, 322-327. doi: 10.1038 /nature 12948

Rissland, O. S., Hong, S. J., and Bartel, D. P. (2011). MicroRNA destabilization enables dynamic regulation of the miR-16 family in response to cell-cycle changes. Mol. Cell 43, 993-1004. doi: 10.1016/j.molcel.2011.08.021

Roesch, A., Fukunaga-Kalabis, M., Schmidt, E. C., Zabierowski, S. E., Brafford, P. A., Vultur, A., et al. (2010). A temporarily distinct subpopulation of slow-cycling melanoma cells is required for continuous tumor growth. Cell 141, 583-594. doi: 10.1016/j.cell.2010.04.020

Ruegger, S., and Grosshans, H. (2012). MicroRNA turnover: when, how, and why. Trends Biochem. Sci. 37, 436-446. doi: 10.1016/j.tibs.2012.07.002

Scheel, C., Eaton, E. N., Li, S. H., Chaffer, C. L., Reinhardt, F., Kah, K. J., et al. (2011). Paracrine and autocrine signals induce and maintain mesenchymal and stem cell states in the breast. Cell 145, 926-940. doi: 10.1016/j.cell.2011.04.029

Schwarz, D. S., Hutvagner, G., Du, T., Xu, Z., Aronin, N., and Zamore, P. D. (2003). Asymmetry in the assembly of the RNAi enzyme complex. Cell 115, 199-208. doi: 10.1016/S0092-8674(03)00759-1

Sempere, L. F., Christensen, M., Silahtaroglu, A., Bak, M., Heath, C. V., Schwartz, G., et al. (2007). Altered MicroRNA expression confined to specific epithelial cell subpopulations in breast cancer. Cancer Res. 67, 11612-11620. doi: 10.1158/00085472.CAN-07-5019

Shackleton, M., Vaillant, F., Simpson, K. J., Stingl, J., Smyth, G. K., Asselin-Labat, M. L., et al. (2006). Generation of a functional mammary gland from a single stem cell. Nature 439, 84-88. doi: 10.1038/nature04372

Shimono, Y., Zabala, M., Cho, R. W., Lobo, N., Dalerba, P., Qian, D., et al. (2009). Downregulation of miRNA-200c links breast cancer stem cells with normal stem cells. Cell 138, 592-603. doi: 10.1016/j.cell.2009.07.011

Song, S. J., Poliseno, L., Song, M. S., Ala, U., Webster, K., Ng, C., et al. (2013). MicroRNA-antagonism regulates breast cancer stemness and metastasis via TET-family-dependent chromatin remodeling. Cell 154, 311-324. doi: 10.1016/j.cell.2013.06.026

Sorlie, T., Perou, C. M., Tibshirani, R., Aas, T., Geisler, S., Johnsen, H., et al. (2001). Gene expression patterns of breast carcinomas distinguish tumor subclasses with clinical implications. Proc. Natl. Acad. Sci. U.S.A. 98, 10869-10874. doi: 10.1073/pnas.191367098

Sotiriou, C., Neo, S. Y., Mcshane, L. M., Korn, E. L., Long, P. M., Jazaeri, A., et al. (2003). Breast cancer classification and prognosis based on gene expression profiles from a population-based study. Proc. Natl. Acad. Sci. U.S.A. 100, 1039310398. doi: 10.1073/pnas. 1732912100

Sotiriou, C., and Pusztai, L. (2009). Gene-expression signatures in breast cancer. $N$. Engl. J. Med. 360, 790-800. doi: 10.1056/NEJMra0801289 
Stingl, J., Eirew, P., Ricketson, I., Shackleton, M., Vaillant, F., Choi, D., et al. (2006). Purification and unique properties of mammary epithelial stem cells. Nature 439, 993-997. doi: 10.1038/nature04496

Taft, R. J., Pheasant, M., and Mattick, J. S. (2007). The relationship between nonprotein-coding DNA and eukaryotic complexity. Bioessays 29, 288-299. doi: 10.1002/bies.20544

Tahiliani, M., Koh, K. P., Shen, Y., Pastor, W. A., Bandukwala, H., Brudno, Y., et al. (2009). Conversion of 5-methylcytosine to 5-hydroxymethylcytosine in mammalian DNA by MLL partner TET1. Science 324, 930-935. doi: 10.1126/science. 1170116

Thiery, J. P., Acloque, H., Huang, R. Y., and Nieto, M. A. (2009). Epithelialmesenchymal transitions in development and disease. Cell 139, 871-890. doi: 10.1016/j.cell.2009.11.007

Thiery, J. P., and Sleeman, J. P. (2006). Complex networks orchestrate epithelialmesenchymal transitions. Nat. Rev. Mol. Cell Biol. 7, 131-142. doi: $10.1038 / \mathrm{nrm} 1835$

Thomas, M., Lieberman, J., and Lal, A. (2010). Desperately seeking microRNA targets. Nat. Struct. Mol. Biol. 17, 1169-1174. doi: 10.1038/nsmb.1921

Tsai, M. C., Manor, O., Wan, Y., Mosammaparast, N., Wang, J. K., Lan, F., et al. (2010). Long noncoding RNA as modular scaffold of histone modification complexes. Science 329, 689-693. doi: 10.1126/science.1192002

Van Keymeulen, A., Rocha, A. S., Ousset, M., Beck, B., Bouvencourt, G., Rock, J., et al. (2011). Distinct stem cells contribute to mammary gland development and maintenance. Nature 479, 189-193. doi: 10.1038/nature10573

Visvader, J. E. (2009). Keeping abreast of the mammary epithelial hierarchy and breast tumorigenesis. Genes Dev. 23, 2563-2577. doi: 10.1101/gad.1849509

Visvader, J. E., and Stingl, J. (2014). Mammary stem cells and the differentiation hierarchy: current status and perspectives. Genes Dev. 28, 1143-1158. doi: 10.1101/gad.242511.114

Viswanathan, S. R., Powers, J. T., Einhorn, W., Hoshida, Y., Ng, T. L., Toffanin, S., et al. (2009). Lin28 promotes transformation and is associated with advanced human malignancies. Nat. Genet. 41, 843-848. doi: 10.1038/ng.392

Wang, D., Cai, C., Dong, X., Yu, Q. C., Zhang, X. O., Yang, L., et al. (2014). Identification of multipotent mammary stem cells by protein $\mathrm{C}$ receptor expression. Nature 517, 81-84. doi: 10.1038/nature13851

Wang, K. C., and Chang, H. Y. (2011). Molecular mechanisms of long noncoding RNAs. Mol. Cell 43, 904-914. doi: 10.1016/j.molcel.2011.08.018

Wang, L., Zeng, X., Chen, S., Ding, L., Zhong, J., Zhao, J. C., et al. (2013a). BRCA1 is a negative modulator of the PRC2 complex. EMBO J. 32, 1584-1597. doi: 10.1038/emboj.2013.95

Wang, Y., Xu, Z., Jiang, J., Xu, C., Kang, J., Xiao, L., et al. (2013b). Endogenous miRNA sponge lincRNA-RoR regulates Oct4, Nanog, and Sox2 in human embryonic stem cell self-renewal. Dev. Cell 25, 69-80. doi: 10.1016/j.devcel.2013.03.002

Wang, Z., Liao, H., Deng, Z., Yang, P., Du, N., Zhanng, Y., et al. (2013c). miRNA205 affects infiltration and metastasis of breast cancer. Biochem. Biophys. Res. Commun. 441, 139-143. doi: 10.1016/j.bbrc.2013.10.025
Wilusz, J. E., Sunwoo, H., and Spector, D. L. (2009). Long noncoding RNAs: functional surprises from the RNA world. Genes Dev. 23, 1494-1504. doi 10.1101/gad.1800909

Wu, L., and Belasco, J. G. (2008). Let me count the ways: mechanisms of gene regulation by miRNAs and siRNAs. Mol. Cell 29, 1-7. doi: 10.1016/j.molcel.2007. 12.010

Yang, J. S., Maurin, T., Robine, N., Rasmussen, K. D., Jeffrey, K. L., Chandwani, R., et al. (2010). Conserved vertebrate mir-451 provides a platform for Dicerindependent, Ago2-mediated microRNA biogenesis. Proc. Natl. Acad. Sci. U.S.A 107, 15163-15168. doi: 10.1073/pnas.1006432107

Yang, Z., Zhou, L., Wu, L. M., Lai, M. C., Xie, H. Y., Zhang, F., et al. (2011). Overexpression of long non-coding RNA HOTAIR predicts tumor recurrence in hepatocellular carcinoma patients following liver transplantation. Ann. Surg. Oncol. 18, 1243-1250. doi: 10.1245/s10434-011-1581-y

Yu, F., Yao, H., Zhu, P., Zhang, X., Pan, Q., Gong, C., et al. (2007). let-7 regulates self renewal and tumorigenicity of breast cancer cells. Cell 131, 1109-1123. doi: 10.1016/j.cell.2007.10.054

Yu, H., Lee, H., Herrmann, A., Buettner, R., and Jove, R. (2014). Revisiting STAT3 signalling in cancer: new and unexpected biological functions. Nat. Rev. Cancer 14, 736-746. doi: 10.1038/nrc3818

Yuan, J. H., Yang, F., Wang, F., Ma, J. Z., Guo, Y. J., Tao, Q. F., et al. (2014). A long noncoding RNA activated by TGF-beta promotes the invasionmetastasis cascade in hepatocellular carcinoma. Cancer Cell 25, 666-681. doi: 10.1016/j.ccr.2014.03.010

Zhang, H., Cai, K., Wang, J., Wang, X., Cheng, K., Shi, F., et al. (2014). MiR-7, Inhibited Indirectly by LincRNA HOTAIR, directly inhibits SETDB1 and reverses the EMT of breast cancer stem cells by downregulating the STAT3 pathway. Stem Cells 32, 2858-2868. doi: 10.1002/stem. 1795

Conflict of Interest Statement: The authors declare that the research was conducted in the absence of any commercial or financial relationships that could be construed as a potential conflict of interest.

Received: 01 December 2014; paper pending published: 27 January 2015; accepted: 11 February 2015; published online: 27 February 2015.

Citation: Tordonato C, Di Fiore PP and Nicassio F (2015) The role of non-coding RNAs in the regulation of stem cells and progenitors in the normal mammary gland and in breast tumors. Front. Genet. 6:72. doi: 10.3389/fgene.2015.00072

This article was submitted to Epigenomics and Epigenetics, a section of the journal Frontiers in Genetics.

Copyright (c) 2015 Tordonato, Di Fiore and Nicassio. This is an open-access article distributed under the terms of the Creative Commons Attribution License (CC BY). The use, distribution or reproduction in other forums is permitted, provided the original author(s) or licensor are credited and that the original publication in this journal is cited, in accordance with accepted academic practice. No use, distribution or reproduction is permitted which does not comply with these terms. 